\title{
Tracing acidification induced by Deccan Phase 2 volcanism
}

Eric Font ${ }^{1 *}$, Jorge Ponte ${ }^{1}$, Thierry Adatte ${ }^{2}$, Alicia Fantasia ${ }^{2}$, Fabio Florindo ${ }^{3}$, Alexandra Abrajevitch $^{4}$ and José Mirão ${ }^{5}$

${ }^{1}$ IDL-FCUL, Instituto Dom Luís, Faculdade de Ciências, Universidade de Lisboa, Campo Grande, 1749016, Portugal

${ }^{2}$ ISTE, Geopolis, CH-1015 Lausanne, Switzerland

${ }^{3}$ Istituto Nazionale di Geofisica e Vulcanologia, Via di Vigna Murata 605, 00143-Rome, Italy

${ }^{4}$ Institute of Tectonics and Geophysics, Russian Academy of Sciences, Khabarovsk, Russia

${ }^{5}$ HERCULES, Evora, Portugal

*Corresponding author: Eric Font, IDL-FCUL, Instituo Dom Luiz, Faculdade de Ciências, Universidade de Lisboa, Edifício C8-8.3.22, Campo Grande, 1749-016, Lisboa, PORTUGAL. e-mail: font_eric@hotmail.com

\section{Abstract}

The Deccan Volcanic Province (DVP) was built up by three major phases of eruptions; the most voluminous of which, the Deccan Phase 2, encompassed the CretaceousPaleogene (KT) boundary. Deccan eruptions have been implicated as a contributor to the end-Cretaceous mass extinction, however, mechanism by which volcanic activity affected biota remains poorly understood. We applied a combination of rock magnetic techniques, scanning electron microscopy and diffuse reflectance spectrophotometry to characterize mineral assemblages of three sections of intertrappean lacustrine sediments from the north-western Maharashtra Deccan Volcanic Provinces. Our results indicate that in sediments deposited during the early stages of the Deccan Phase 2, the Daïwal River and Dhapewada sequences, iron-bearing mineral association is dominated by detrital iron oxides (magnetite and hematite) sourced from the weathering of the surrounding basaltic bedrocks, with minor contribution form authigenic iron sulphides (framboidal pyrite, pyrrhotite and/or greigite). The sediments deposited during the final stages of Phase 2 (the Podgawan sequence) differ significantly in their characteristics. 
In particular, the Podgawan sediments have 1) very low magnetic susceptibility values, but higher terrigenous fraction (clays and shales) content; 2) more complex assemblage of magnetic minerals, 3) ubiquitous presence of Fe-Ca-Ce vanadates; and 4) unusual lithological variations in the middle part of the section (represented by a charcoal-rich level that is capped by a red clay layer containing fossilized bacterial colonies). We suggest that these unusual characteristics reflect increased acidity in the regionduring the deposition of the Podgawan sequence, likely due to cumulative effects of volcanic aerosols released during the Deccan Phase 2 eruptions. The combination of these features may be used to recognize episodes of increased acidity in the geological record. Our results also contribute to understanding of local vs. global effects of the Deccan volcanism.

Keywords: Deccan Volcanic Province, intertrappean continental sediments, environmental magnetism, acidification, India.

\section{Introduction}

The Deccan Volcanic Province (DVP) is one of the largest igneous provinces of the Earth (Courtillot et al., 1988; Wignall, 2001e.g., ). The DVP is represented by three discrete volcanic phases with variable eruption intensity. Based on volcanic stratigraphy of the Western Ghats, magnetostratigraphy and ${ }^{40} \mathrm{~K}-{ }^{40}$ Ar dating (Chenet et al., 2007; Jay et al., 2009), three phases have been identified: Phase-1 ( 67.5 Ma), Phase 2 ( 66 Ma) and Phase-3 ( 64.5 Ma). The Deccan Phase 2 is considered by far the most voluminous and the most severe episode of the magmatic history of the DVP; it also coincides temporally with the Cretaceous-Paleogene (KT) boundary mass extinction (Chenet et al., 2007; Courtillot et al., 1986; Courtillot and Renne, 2003; Font et al., 2014; Keller et al., 2012; Keller et al., 2011; Sial et al., 2013; Wignall, 2001). Recent U-Pb dating on 
zircons collected in the bole beds (intertrappean deposits) of the Ambenali section, western Gaths (India), showed that the main phase of eruptions initiated $\sim 250,000$ years before the KT boundary and that more than 1.1 million $\mathrm{km}^{3}$ of basalts erupted in $\sim 750,000$ years (Schoene et al., 2015). The volume of lava extruded during the Deccan Phase 2 is estimated at $\sim 10^{6} \mathrm{~km}^{3}$, which represents $\sim 80 \%$ of the volcanic pile, while Phases 1 and 3 represent $6 \%$ and $14 \%$ of the total volume, respectively (Chenet et al., 2007; Jay and Widdowson, 2008). Each eruptive episode may have produced more than $1000 \mathrm{~km}^{3}$ lavas (Self et al., 2006). For every cubic kilometre of lava erupted, the Deccan magmas are estimated to release as much as $3.5 \mathrm{Tg}$ of $\mathrm{SO}_{2}$ and $1 \mathrm{Tg}$ of $\mathrm{HCl}$ (Self et al., 2008). The absence of secular paleomagnetic variations and volcanological constraints suggest that the whole, $3500 \mathrm{~m}$ thick, Deccan volcanic pile was accumulated in less than $1 \mathrm{Ma}$, while each individual eruptive event lasted less than a decade (Chenet et al., 2009; Chenet et al., 2008; Courtillot and Fluteau, 2014).Environmental stressinduced by volcanism depends on the size of thevolcanic province, and, more critically, on the rate at which eruptions tookplace. The large amount of volcanic aerosols released within such a short time interval during the Deccan eruptions would likely have caused severe environmental perturbations, at least regionally (Samant and Mohabey, 2014; Samant et al., 2008), and likely globally (Font and Abrajevitch, 2014; Font et al., 2014; Gertsch et al., 2011; Keller, 2014; Ward, 2009). However, how environmental signal of the DVP is expressed in the sedimentary records and how the eruptions may have contributed to the KT mass extinction remain poorly understood.

Here we attempt to unravel the impact of Deccan eruptions on the regional paleoenvironment by studying mineral assemblages of lacustrine and terrestrial intertrappeans sediments of the DVP. Intertrappean Deccan sediments represent periods of volcanic quiescence and are therefore crucial for understanding eruptive history of 
the Deccan Traps and paleo-weathering and paleo-climatic climatic conditions in the region (Adatte and Keller, 2013; Courtillot et al., 2000; Ghosh et al., 2006; Keller et al., 2009; Khadkikar et al., 1999; Shrivastava et al., 2012).

We used rock magnetic parameters complemented by optical observations and semiquantitative compositional analysis under a Scanning Electron Microscope to identify mineral phases in the sediments; mineral assemblages were then used to infer the environmental conditions that led to their formation.

We focused on three lake sediment sequences interstratified within Deccan Phase-2 lava flows: the Daiwal River, the Dhapewada and the Podgawan (Fig. 1). Paleomagnetic data from the underlying and overlying lavas indicate that all section formed during the geomagnetic polarity chron 29r (M. Widdowson, pers. communication), and thus are of the Maastrichtian to early Paleocene age. Previous palynological data (Samant and Mohabey, 2005, 2009, 2014; Samant et al., 2008), as well as new sedimentological and chemostratigraphic data (Fantasia et al., this volume) provided a framework for our study. Particularly, the critical regional environmental impact of the Deccan eruptions has been evidenced based upon the comparison of the geochemical and mineralogical between the infrabasaltic Lameta Formation and the intertrappean sediments (including those under study) (Fantasia et al., this volume). The intertrappean sediments within phase- 2 are characterized by low content in calcite, severe organic matter degradation, high volcanic content associated elements ( $\mathrm{Ti}$ and $\mathrm{Fe}$ ), high $\mathrm{Ti} / \mathrm{Al}$ ratios and high chemical alteration (CIA-K) that likely reflects increasing weathering and acid rains rather than climatic change (Fantasia et al., this volume, accepted with minor revision). A particular attention was given to the Podgawan section, which was deposited at the end of Deccan Phase 2, and may encompass the Cretaceous-Tertiary boundary (Keller et al., 2011). 


\section{Geological Settings and sampling}

The term "intertrappeans" refers here to continental siliciclastic and carbonate sediments deposited in lacustrine continental settings, not to be confused with the term "bole bed", which corresponds to thin levels of red and green clay deposits interpreted as the erosion product of the underlying basalts, eventually mixed with volcanic ashes(Widdowson et al., 1997). These depositsmostly crop out incentral India in the fringe area of the eastern part of the DVP, namely in the Nand-Dongargaon and Yeotmal-Nanded areas of the Maharashtra sub-province and in the ChhindwaraMandla-Sivni-Jabalpur sector in the Madhya Pradesh area (Fig. 1). Palynological and biostratigraphic criteria (Samant and Mohabey, 2005, 2009, 2014) indicated that the Daïwal River (DA) and the Podgawan (Po) sections, located in the Nand-Dongargaon area, are included in the Deccan Phase 2. Paleomagnetic data also indicated that all sections of the Nagpur region formed during the geomagnetic polarity chron 29r $(M$. Widdowson, pers. communication). The Daïwal section is located between the first two flows of the Ajantha Formation, whereas the Podgavan section is younger and is located between at the top of the volcanic pile (Fig. 1).

The Daïwal section is located in the Chandrapur District of Maharashtra in a tributary of the Daïwal River $\left(20^{\circ} 16^{\prime} 45.8^{\prime \prime} \mathrm{N}, 78^{\circ} 55^{\prime} 00.8^{\prime \prime} \mathrm{E}\right)$ near the village Panjurni (Fig. 1). The sedimentary succession is $4.5 \mathrm{~m}$ thick and is composed by laminated porcelanite, grey and black cherts, all with various degree of silicification. The sediments contain abundant fossils of ostracods, gastropods and fishes. The lacustrine sediments are in irregular contact with the underlying basalt flow. The lower basalt is strongly weathered and has a network of vertical fractures filled with grey siliceous sediments. 
The Dhapewada section was sampled in a quarry located between the towns of Dhapewada and Waroda $\left(21^{\circ} 17^{\prime} 07.4^{\prime \prime} \mathrm{N}, 7^{\circ} 54^{\prime} 47.6^{\prime \prime} \mathrm{E}\right)$ (Fig. 1), where sedimentary succession is continuously exposed over several ten of meters.Sediment lithology changes (from the base to the top) from laminated variegated clays (paleosols), siltstones rich in diatoms, silty clays, porcelanite with gastropods, charophytes and pyrite, black chertto yellow clays at the top.

The Podgawan section is located in the Yavatmal District of the Maharashtra State near the town of Yeotmal $\left(20^{\circ} 22^{\prime} 17.1^{\prime \prime} \mathrm{N}, 78^{\circ} 26^{\prime} 20.7^{\prime \prime} \mathrm{E}\right)$ (Fig. 1). Here, the complete sedimentary succession, including the underlying and overlying basalt flows, was sampled in two trenches. The base of the section is characterized by monotonous green siltstones, which grade upwards into brownish siltstones alternating with $2-5 \mathrm{~cm}$ thick

carbonate layers. Three calcrete levels occur at the base of the section, suggesting period of drying out leading to emersion under arid conditions. Above, thick brown fossiliferous silty claystones are intercalated with $2-5 \mathrm{~cm}$-thick marly limestone layers. In the upper part of the sequence, three distinct levels are represented by a grey chert layer (PoA 12) and a coal-rich level (PoA 14) capped by a thin reddish clay-rich layer (PoA 16). The top of the section is composed by marly limestone containing gastropods with aragonitic shells.

\section{Methods and sampling}

Samples collected in the field were crushed in an agate mortar and pestle and filled into $2 \times 2 \times 2 \mathrm{~cm}^{3}$ plastic cubic boxes (standard size for the JR-6 spinner magnetometer) for subsequent magnetic measurements. Magnetic measurements were performed in the Paleomagnetism Laboratory of the Instituto Dom Luís (IDL) of Lisbon, Portugal. Remanence was measured by using a JR- 6 magnetometer (sensitivity of $2.4 \times 10^{-6} \mathrm{~A} / \mathrm{m}$ ). 
Low-field magnetic susceptibility $(\chi)$ and frequency-dependent magnetic susceptibility $\left(\chi_{\mathrm{fd}}\right)$ was measured with a MFK1 (AGICO) apparatus and reported as mass-normalized values $\left(\mathrm{m}^{3} / \mathrm{kg}\right) . \mathrm{K}_{\mathrm{fd}}$ was calculated by using the formula $\mathrm{K}_{\mathrm{fd}}(\%)=\left[\mathrm{K}_{\mathrm{lf}}-\mathrm{K}_{\mathrm{hf}}\right] / \mathrm{K}_{\mathrm{lf}} * 100$, where $\mathrm{K}_{\mathrm{hf}}$ is high frequency $(15616 \mathrm{~Hz})$ susceptibilityand $\mathrm{K}_{\mathrm{lf}}$ is low frequency $(976 \mathrm{~Hz}$ ) susceptibility. $\mathrm{K}_{\mathrm{hf}}$ and $\mathrm{K}_{\mathrm{lf}}$ were obtained from the average of three independent measurements. Thermomagnetic measurements ( $\chi$-T curves) were conducted in Argoncontrolled atmosphere. After minimizing the influence of magnetic interactions by limiting the AF steps to $100 \mathrm{mT}$ (Heslop et al., 2004), room-temperature isothermal remanent magnetization (IRM) acquisition curve was made with an impulse magnetizer (model IM-10-30).Statistical analysis of the IRM acquisition curves were conducted by using a cumulative log-Gaussian (CLG) function (Kruiver et al., 2001; Robertson and France, 1994). The S-ratio was calculated with the formula $-\mathrm{IRM}_{-0.3 \mathrm{~T}} / \mathrm{IRM}_{1 \mathrm{~T}}$.

Hysteresis runs and First-order reversal curve (FORC) measurements (Pike et al., 1999; Roberts et al., 2014; Roberts et al., 2000) were made at room temperature on small subsamples ( $\sim 50 \mathrm{mg})$ using a vibrating sample magnetometer (VSM, Princeton Measurements Corporation Model 3900 Micromag) at the Istituto Nazionale di Geofisica e Vulcanologia (INGV) in Rome. These samples were taken from representative intervals to investigate micro-coercivity and magnetic interaction field distributions for the magnetic particles. Data were processed, smoothed, and plotted using the FORCINEL program (Harrison and Feinberg, 2008).For several representative samples, the contribution of SP grains was also estimated using the method ofWang et al. (2010) as $\mathrm{M}_{\mathrm{RS}}(\mathrm{SP}) \%=100\left(\mathrm{M}_{\mathrm{RS} 0}-\mathrm{M}_{\mathrm{RS} 100}\right) / \mathrm{M}_{\mathrm{RS} 0}$, where $\mathrm{M}_{\mathrm{RS}}(\mathrm{SP}) \%$ is $\mathrm{SP}$ particle content, $\mathrm{M}_{\mathrm{RS} 0}$ is the remanence measured after application of a $1 \mathrm{~T}$ "saturating field" and $\mathrm{M}_{\mathrm{RS} 100}$ is measured $100 \mathrm{~s}$ after field application. 
Optical investigations of fresh rock fragments and glass plates were conducted under a Hitachi S-3700N SEM microscope coupled to a Bruker XFlash® 5010 EDS detector at the Hercules laboratory (Évora, Portugal).The electron source for the SEM is a tungsten wire. The accelerate voltage is $20 \mathrm{keV}$. Qualitative compositional analysis was provided by energy dispersive spectra (EDS) by using the ESPRIT Software (Bruker).

\section{Rock magnetism}

\section{Daïwal River}

Concentration- (SIRM, $\chi)$ and coercivity-dependent ( $\mathrm{B}_{1 / 2}$, S-ratio) parameters are illustrated in Figure 2. The Daïwal River samples have very low $\chi$ values $\left(\sim 10^{-7} \mathrm{~m}^{3} \mathrm{~kg}^{-}\right.$

${ }^{1}$ ), approximately one order of magnitude lower than that of the Dhapewada samples. Lower $\chi$ values likely reflect the smaller terrigenous fraction content of the Daïwal River sediments. By comparison, glacial lacustrine sediments from Australia and northwestern Europe, similarly developed on basaltic bedrock, exhibit maximum values of $10^{-6} \mathrm{~m}^{3} / \mathrm{kg}^{-1}$ (Thompson and Oldfield, 1986).

Three main magnetic components are identified by unmixing IRM acquisition curves using a cumulative log-Gaussian function (Heslop et al., 2002; Kruiver et al., 2001; Robertson and France, 1994). The first low coercivity component (comp. 1) has mean coercivity $\left(B_{1 / 2}\right.$, field at which half saturation magnetization is achieved) of 15-25 mT and a wide dispersion (DP, the width of distribution given by one standard deviation) of 30-34, typical of coarse (detrital) magnetite commonly found in sedimentary rocks. Component 1 contributes to less than $25 \%$ of the total remanence of the sediments, but up to $100 \%$ in the lower basalt (sample DA1, Table 1). Intermediate coercivity

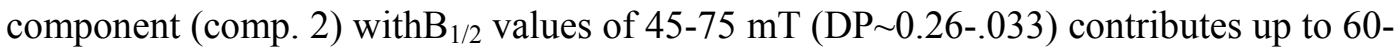


$85 \%$ of the total remanence of the sediments and the upper basalt (DA25; Table 1). The high coercivity component (comp. 3) is characterized by the $\mathrm{B}_{1 / 2} \sim 190-320 \mathrm{mT}$ and $\mathrm{DP} \sim 0.3-0.4$, corresponding to the coercivity range of hematite. Contribution of component 3 into the total IRM of the samples does not exceed 20\% (Table 1). Goethite is likely to be present in our samples, however, it cannot be reliably detected at the maximum applied filed $(1 \mathrm{~T})$ of our equipment. S-ratio near 0.9 indicates that low coercivity phases provide the main contribution into the total SIRM (Fig. 2).

High-temperature thermomagnetic $(\chi-T)$ curves of sample DA10 (diatomite) and sample DA1 (lower basalt) are shown in Fig. 3A. Susceptibility of the lower basalt (DA1) sample increases slightly upon heating to $\sim 300^{\circ} \mathrm{C}$, and then decreases to the initial values at $350-400{ }^{\circ} \mathrm{C}$. Such hump at $300{ }^{\circ} \mathrm{C}$ may indicate the presence of maghemite (either detrital, or produced during the heating process), with maghemite inversion to hematite at $350-400{ }^{\circ} \mathrm{C}$ leading to the decrease in susceptibility (Dunlop and Özdemir, 1997). Upon further heating, $\chi$ values drops abruptly at $580^{\circ} \mathrm{C}$, the Curie temperature of magnetite. In the diatomite sample, the identification of Curie temperatures is hampered by the very low $\chi$ and by mineralogical transformation occurring during heating (e.g., magnetite formation noted by Curie temperature at 580 ${ }^{\circ} \mathrm{C}$ in the cooling cycle). However, a slight but significant drop in $\chi$ is observed at the Curie temperatures of titanomagnetite $\left(\sim 500^{\circ} \mathrm{C}\right)$ and hematite $\left(\sim 680^{\circ} \mathrm{C}\right)$ (DA10, Fig. $3 \mathrm{~A})$.

Grain size of magnetic particles contained in the DA sediments and basalts can be estimated by comparing measured hysteresis parameters with the theoreticalmixing curves (Dunlop, 2002a; Dunlop, 2002b) (Fig. 4). The lower and upper basalts samples typically lie along the mixing lines of single-domain (SD) and multidomain (MD) end members or correspond to true pseudo-single domain (PSD) grain-size ranges. DA 
sediments show a trend similar to that of the basalt samples, although grain-size estimate for the sediments may be compromised by the admixture of hard coercivity hematite. The FORC diagram for sample DA23 is dominated by a low-coercivity MD component (Fig. 2). $\mathrm{M}_{\mathrm{RS}}(\mathrm{SP}) \%$ of $3.9 \%$ estimated from hysteresis ration indicates a small contributionform SP grains in this sample, while the high coercivity (up to 1000 $\mathrm{mT}$ ) tail in the IRM acquisition experiment, indicatesthe presence of hematite (i.e., comp. 3; Fig. 3). The FORC diagrams for basalt samples (DA-1, lower basalt; DA-25, upper basalt) are dominated by a SD component; the contribution of SP grains is somewhat larger in the lower basal unit.

The similarity in the coercivity range, number of CLG components, and grain size distribution between the basalts (DA1 and DA25) and the lacustrine sediments strongly suggest that magnetic carriers of the Daïwal sediments are of detrital origin and were inherited from the weathering of the basaltic bedrock. Low contentof SP particles that generally formduring pedogenic processes suggest poor soil development in the lake catchment.

\section{Dhapewada}

Magnetic data of the Dhapewada section are illustrated in Figure 5. The Dhapewada samples have low $\chi$ values on the order of $10^{-6} \mathrm{~m}^{3} / \mathrm{kg}$, comparable to that of glacial lacustrine sediments developed upon basaltic bedrock (Thompson and Oldfield, 1986). Low field susceptibility values of the Dhapewada samples are $\sim$ two orders of magnitude higher than those of the siliceous Daïwal sediments due to the higher clay content. Susceptibility varies little with depth, except for samples Dhap10 and Dhap15 that have high $\chi$ values (Fig. 5). 
Three magnetic components were identified by unmixing IRM acquisition curves. Component 1 has mean coercivity $\left(\mathrm{B}_{1 / 2}\right)$ of $15-18 \mathrm{mT}$ and $\mathrm{DP}$ values of $0.25-0.30$ (Table 1). Component 2 has mean coercivity $\left(\mathrm{B}_{1 / 2}\right)$ of $42-57 \mathrm{mT}$ and a wide DP of 0.28 to 0.38 . Coercivity ranges of these two components are consistent with that of (titano-) magnetite. Component 3 defined by typical of hematite values $B_{1 / 2}$ of $223-252 \mathrm{mT}$ and DP values of $0.30-0.40$. S-ratio close to 1 indicate that a low coercivity mineral, likely magnetite, is the main contributor tothe remanence. S-ratio and $B_{1 / 2}$ values show very little variations along the profile, suggesting that the composition of the magnetic assemblage is similar in all lithological varieties. The concentration of the magnetic fraction, however, varies significantly. For example, SIRM intensity of component 1 rangesbetween $10^{-3}$ and $10^{-7} \mathrm{Am}^{2} / \mathrm{kg}$ (Fig. 5), while SIRM intensities of component 2 and 3 vary between $10^{-3}$ and $10^{-5}$ and between $10^{-4}$ and $10^{-6} \mathrm{Am}^{2} / \mathrm{kg}$, respectively. The two peaks observed in the $\chi$ profile correspond to the high SIRM values (Fig. 5).

Thermomagnetic curves $(\chi-T)$ of Dhapewada samples (Dhap4, Dhap10 and Dha15) show two prominent humps in the heating curve, one at $\sim 280{ }^{\circ} \mathrm{C}$ and the other at $\sim 480$ ${ }^{\circ} \mathrm{C}$ (Fig. 3B). After the first hump at $\sim 280{ }^{\circ} \mathrm{C}, \chi$ decreases rapidly up to $\sim 380-400{ }^{\circ} \mathrm{C}$, whereas Curie temperatures of the second phase fall at $\sim 580{ }^{\circ} \mathrm{C}$, typical of magnetite's Curie temperature. On further heating, $\chi$ decreases gradually up to $680{ }^{\circ} \mathrm{C}$, the Curie point of hematite. On the cooling curve, only one hump at $525{ }^{\circ} \mathrm{C}$ with Curie point of $560{ }^{\circ} \mathrm{C}$ remains visible. The divergence of heating and cooling curves suggests that mineralogical transformation during heating result in formation of magnetite. The hump at $280{ }^{\circ} \mathrm{C}$ may be associated with the presence of titanomagnetite or iron sulphide (pyrrhotite or greigite). Monoclinic pyrrhotite $\left(\mathrm{Fe}_{7} \mathrm{~S}_{8}\right)$ is ferromagnetic with a maximum Curie temperature at $325^{\circ} \mathrm{C}$, while hexagonal pyrrhotite $\left(\mathrm{Fe}_{9} \mathrm{~S}_{10}\right)$ is ferromagnetic over temperature ranges between the so-called $\lambda$ transition (corresponding to the temperature 
at which thermally activated vacancy ordering occurs) and the Curie point at $\sim 265^{\circ} \mathrm{C}$ (Dunlop and Özdemir, 1997; Rochette et al., 1990). Greigite is stable up to $280{ }^{\circ} \mathrm{C}$ and begins to break down to form minor pyrrhotite, pyrite and marcasite above this temperature (Krs et al., 1990; Roberts, 1995; Roberts et al., 2011).To distinguish between greigite and pyrrhotite, we conducted partial stepwise heating-cooling runs of sample Dhap10 (Fig. 3C). Titanomagnetite can be excluded by the absence of the hump at $280{ }^{\circ} \mathrm{C}$ after a complete high-temperature cycle (Fig. 3C). Below $400{ }^{\circ} \mathrm{C}$, heating and cooling curves are reversible, which is compatible with pyrrhotite, but not with greigite. Upon heating between $400{ }^{\circ} \mathrm{C}$ and $450{ }^{\circ} \mathrm{C}, \chi$ increases rapidly and cooling/heating cycles are no longer reversible, indicating that a new magnetic phase (magnetite?) has been created during heating. This transition may correspond to the transformation of pyrrhotite to magnetite. Subsequent heating to above $600{ }^{\circ} \mathrm{C}$ showed that the newly formed magnetic phase corresponds to magnetite with Curie temperature of $580{ }^{\circ} \mathrm{C}$. This magnetite is stable up to $600{ }^{\circ} \mathrm{C}$, as shown by the reversible character of the heating and cooling curves. Above $600{ }^{\circ} \mathrm{C}$, magnetite is progressively oxidized to hematite, as indicated by significantly lower $\chi$ values on the cooling curve and a small, but significant, $\chi$ decrease between $580{ }^{\circ} \mathrm{C}$ to $680{ }^{\circ} \mathrm{C}$. Overall, thermomanetic curves indicate that pyrrhotite and magnetite are the main magnetic carriers in the Dhapewada samples. However, because of the chemical alteration during heating, we are unable to confidently distinguish the primary (detrital) magnetite from the neoformed magnetite. The content of superparamagnetic particles in the Dhapewada samples is low, as indicated by the low $\chi$ fd values $(<3 \%)$ (Fig. 5). Hysteresis parameters are closed to the line of SD+MD mixtures when compared to theoretical mixing curves (Fig. 4). FORC diagrams suggest a mixed contribution from non-interacting SD particles (closed contours, peaked at around $\mathrm{Bc}=10 \mathrm{mT}$ ) and viscous magnetizations carried by $\mathrm{SP}$ 
ultrafine particles, as outlined by the slightly asymmetric diverging contours that are parallel to the $\mathrm{Hu}$ axis.

\section{Podgawan}

Magnetic data of the Podgawan samples are illustrated at Figure 6. Despite the high content of terrigenous elements (they are mostly composed of clays and shales), the Podgawan section sediments have low $\chi$ on the order of $10^{-7} \mathrm{~m}^{3} / \mathrm{kg}$. In the middle part of the section, a prominent $\chi$ peak is observed at the level of sample POA16, a red clay layer that caps a coal level (Fig. 6). Small decreases in susceptibility are noted in carbonate-rich samples POA5 to POA14. The lower and upper Deccan lava flows have high $\chi$ of $25 \times 10^{-7}$ and $45 \times 10^{-7} \mathrm{~m}^{3} / \mathrm{kg}$, respectively, which represent one order of magnitude higher than the intertrappeans deposits.

The lower basalt contain a single low coercive phase $\left(B_{1 / 2}=33 \mathrm{mT}\right)$, probably corresponding to (titano) magnetite, while the upper basalt contain two components indicative of the presence of magnetite $\left(\mathrm{B}_{1 / 2}=25 \mathrm{mT}\right)$ and hematite $\left(\mathrm{B}_{1 / 2}=160 \mathrm{mT}\right)$. For the intertrappeans sediments, the best fit of IRM acquisition curves is obtained with four CLG components: component $1\left(\mathrm{~B}_{1 / 2}=17-25 \mathrm{mT}\right.$; DP $\left.=0.23-0.32\right)$, component $2\left(\mathrm{~B}_{1 / 2}=\right.$ $42-56 \mathrm{mT} ; \mathrm{DP}=0.18-0.35)$, component $3\left(\mathrm{~B}_{1 / 2}=100-150 \mathrm{mT} ; \mathrm{DP}=0.19-0.36\right)$ and component $4\left(\mathrm{~B}_{1 / 2}=440-570 \mathrm{mT}\right.$; $\left.\mathrm{DP}=0.25-0.35\right)$ (Fig. 6). Components 1 and 2 have coercivity values comparable to soft and medium coercivity magnetite; while component 3 and 4 probably correspond to maghemite and hematite. $\mathrm{B}_{1 / 2}$ values are almost constant along the sedimentary pile, except some minor variations observed around the red clay/coal levels. SIRM values of all components are generally low, on the order of $10^{-4}$ to $10^{-6} \mathrm{Am}^{2} / \mathrm{kg}$, except in the red clay (POA16) where the SIRM intensities of all components increase significantly (SIRM of comp. 1 is on the order of 
$10^{-3} \mathrm{Am}^{2} / \mathrm{kg}$ ). In the majority of the samples,S-ratios are close to 1 , which is indicative of magnetite as the dominant remanence carrier; but fall to $0.85-0.90$ just below and at the red clay (POA16) level, indicating a relative enhancement in the high coercivityfraction (hematite/goethite) in these samples (Fig. 6). S-ratio of the lower and upper Deccan lava flows are 0.99 and 0.90, respectively, which suggest that the percentage contribution of soft and hard magnetic material is comparable between the lava flows and the intertrappean sediments.

Temperature-dependence of magnetic susceptibility for four representative Podgawan samples are illustrated in Figure 3D. The thermomagnetic curves vary depending on the sample lithology. Clay-rich sediments at the base of the sedimentary pile (sample PoB9) show a mixture of titanomagnetite (Curie point at $\sim 480{ }^{\circ} \mathrm{C}$ ), magnetite (Curie point at $\sim 580^{\circ} \mathrm{C}$ ) and hematite (Curie point at $680^{\circ} \mathrm{C}$ ). A slight decrease in $\chi$ observed from room temperature up to $\sim 250{ }^{\circ} \mathrm{C}$ can be attributed to paramagnetic minerals. Heating and cooling curves for this sample are not identical, indicating that some mineralogical transformations had taking place during heating (Fig. 3D). Sample POA7 corresponds to a calcrete bed from the middle part of the sequence. It shows very low $\chi$ values that gradually decrease from room temperature up to $680{ }^{\circ} \mathrm{C}$, probably resulting from a major contribution of paramagnetic minerals (clays). Secondary magnetite created during heating hampered identification of the initial magnetic phases in this sample. Alteration of iron-bearing phyllosilicates (like smectite) during heating probably represents the main source for the conversion of new magnetite (e.g. Hirt et al., 1993) Interestingly, samples POA14 (coal) and sample POA16 (red clay) show unusual features. The coal level is characterized by nearly identicalheating and cooling curves with Curie point of $560-580{ }^{\circ} \mathrm{C}$, indicative of magnetite. The reversible behaviour indicates the absence of mineralogical transformation during heating and, indirectly, 
suggests that the sample has been previously burnt at high temperature so that no thermally unstable phases remain in the rock. The red clay sample shows several inflexions on the heating curve at $\sim 180,320,440,580$ and $680{ }^{\circ} \mathrm{C}$, indicative of a complex mixture of magnetic phases.

Hysteresis parameters show a narrow distribution that follows the $\mathrm{SD}+\mathrm{MD}$ or, alternatively, the SP+PSD mixing curves of Dunlop (2002a,b) (Fig. 4). FORC diagrams suggest a mixed contribution from non-interacting SD particles and SP ultrafine particles. However, Kfd values of $<5 \%$ suggest that content of SP particles in the sediments is rather small, except for the red clay sample, where higher contribution of SP particles is indicated by $\mathrm{Kfd}$ and $\mathrm{M}_{\mathrm{RS}}(\mathrm{SP}) \%$ values exceeding $10 \%$.

\section{Scanning Electron Microscopy}

Scanning Electron Microscopy (SEM) photographs and semi-quantitative Energy Dispersive Spectra (EDS) compositional analyses are illustrated in Figures 7, 8 and 9. We observed three samples from the Dhapewada section (Dhap3, Dhap16 and Dhap17) and seven samples from the Podgawan section (POB1, 2, 11, 12, 13, 14 and POA16).

\section{Dhapewada}

Sample Dhap3 contains framboidal assemblages of individual cubic-like crystals of small $(<1 \mu \mathrm{m})$ iron oxides (magnetite?; Fig. 7A). Such iron oxide has likely originated from oxidation of pyrite, a phenomenon commonly observed in remagnetized carbonates (Brothers et al., 1996; Font et al., 2006; Suk et al., 1990; Suk et al., 1993; Sun and Jackson, 1994). Titanomagnetites are ubiquitously observed in all samples as

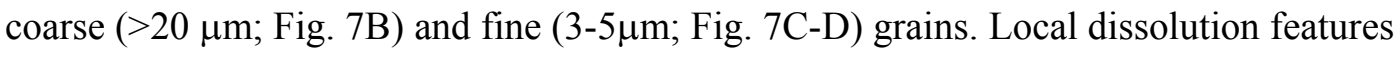


are observed on the surface of some magnetite crystals (Fig. 7B). Iron oxides are either eroded, indicating significant transport and/or dissolution effects, or have euhedral shapes, like the Ti-rich magnetite (ulvöspinel-like morphology)crystal in Dhap3 sample collected from a clay corresponding to paleosols of swamp-ponds (Figure 7D). Euhedral shape is suggestive of a more proximal source. Ti-free iron (hydr-)oxides are also frequently observed (Fig. 7E). Rare iron sulphides grains are also observed (Fig. 7F).

\section{Podgawan}

Typical iron oxides grains from the underlying Deccan Basalts of the Podgawan section are illustrated in Figure 8A. They correspond to magnetite and titanomagnetite (with moderate $\mathrm{Ti}$ content) and have cubic-like morphologies and sub-euhedral shapes. Similar Ti-bearing iron oxides with variable $\mathrm{Ti}$ content are also observed in the overlying Podgawan sediments (Fig. 8B). Grain sizes range between $\sim 2$ and $20 \mu \mathrm{m}$, and are similar in all lithologies. Exsolution features are frequently observed in magnetite and ilmenite grains (Fig. 8C-D) and can developed during magma cooling, metamorphism and/or during post-depositional dissolution processes (Basu and Molinaroli, 1989; Dunlop and Özdemir, 1997; Morad and Aldahan, 1986). Pyrite framboids, frequently replaced by magnetite, are ubiquitous in the set of samples (Fig. 8E). An isolated crystal of pyrrhotite, recognizable by typical plate-like and semihexagonal shape, as well asby the association of Fe and S in EDS spectra (Fig. 8F), has been observed in sample POB2 (clay). Small (5-10 $\mu \mathrm{m})$ eroded crystals of sylvite - a potassium chloride $(\mathrm{KCl})$ mineral forming in evaporitic conditions, are frequently observed (Fig. 8G). We also observed an isolated spherical particle composed of carbon (Fig. 8H), which is likely to correspond to globose chlamydospores of Glomus-like arbuscular mycorrhizal fungi(Samant and Mohabey, 2014). Unlike other studied 
sections, the Podgawan sediments contain ubiquitous $\mathrm{Ca}$ - and Fe-rich vanadates that occur as large $(>50 \mu \mathrm{m})$ and small $(\sim 10 \mu \mathrm{m})$ anhedral crystals (Fig. 9A-B). Their composition include Vanadium, Calcium, Iron and Cerium (Fig. 9B), and is comparable to the composition of montroseite $\left(\left(\mathrm{V}^{3+}{ }_{0.6}, \mathrm{Fe}^{3+}{ }_{0.3}, \mathrm{~V}^{4+}{ }_{0.1}\right) \mathrm{O}(\mathrm{OH})\right)$ or hewettite $\left(\mathrm{CaV}^{5+}{ }_{6} \mathrm{O}_{16} .9\left(\mathrm{H}_{2} \mathrm{O}\right)\right)$. In samplePOA14 (charcoal-rich bed), high resolution observation of vanadate clusters revealed aggregates of very fine $(\sim 1 \mu \mathrm{m})$ individual crystals with euhedral shapes and disk-like morphologies (Fig. 9A-B).

The red clay layer (POA16) located just above the coal layer (POA14) have unusual mineralogical associations. At low-resolution (x400), we observed thin crusts of iron oxide/hydroxide (with low Fe:O ratio that is more consistent with hydroxide) (Fig. 9E). At higher resolution (x2100; Fig. 9F), the iron crust has a botryoidal habit resembling to honeycomb structures constituted by individual micrometric spherical iron oxides (Fig. 9G-H). Iron oxide microspheres are often assembled in linear clusters, resembling bacterial chains (Fig. 9G).Figure 9H shows relationship between $\mathrm{FeO}$ microspheres are the honeycomb structures. A large $(\sim 30 \mu \mathrm{m})$ iron oxide (Fe and $\mathrm{O}$ in EDS spectra) exhibit a botryoidal texture with nanometric scale perforations. Such structures resemble fossilized bacterial colonies (Westall, 1999). Masses of needle-fibre calcite are also frequently observed in the sample aswell-crystallized grains $10-20 \mu \mathrm{m}$ in length and less than $1 \mu \mathrm{m}$ in diameter (Fig. 9E-F).

\section{Discussion}

\subsection{Preservation of primary mineral assemblage}

Sedimentological criteria, SEM observations and magnetic properties collectively suggest that the studied rocks have not suffered significant late diagenetic 
transformations. Smectite, the dominant clay mineral in the studied sediments (Fantasia et al., this volume), is sensitive to high temperature alteration. When heated during sedimentary or tectonic burial, or during episodes of hydrothermal fluid migration, smectite transforms into chlorite or illite (Deconinck and Debrabant, 1985; Ferry et al., 1983; Kubler and Jaboyedoff, 2000). The predominance of smectite in the absence of illite and only minor amounts of (likely detrital) chlorite present, the absence of typical products of hydrothermal alteration, such as corrensite and talc, as well as pristine preservation of aragonitic gastropod shells (Fantasia et al., this volume) indicate that the studied intertrappean sediments have not been strongly altered. Magnetic properties, together with the observation of detrital Ti-bearing iron oxides under SEM, are not supportive of pervasive alteration. Hysteresis parameters of all studied samples fall into the SD+MD region of the modified Day plot (Dunlop, 2002b) that is statistically distinct from the typical trends of carbonates remagnetized by chemical processes or during burial (Channell and Mccabe, 1994; Jackson, 1990; Trindade et al., 2004) (Fig. 4). Accordingly, we conclude that the sedimentary rocks under study were not strongly affected by late diagenesis, and thus, their properties can be used to infer paleoenvironmental conditions during the Deccan Traps eruptions.

\subsection{Early-Phase 2 (Dhapewada and Daïwal River) sediments}

Lake sediments usually contain a mixture of allogenic (transported) and authigenic (formed in situ through biotic or abiotic processes during early or late diagenesis) magnetic minerals. Detrital iron oxides (titano-) magnetite and hematite, iron sulphides pyrrhotite and greigite that can either be detrital or late diagenetic in origin, and fossil magnetosomes of magnetotactic bacteria have been identified in various lake sediments

(e.g., Horng and Roberts, 2006; Liu et al., 2012; Roberts et al., 2011; Roberts and 
Weaver, 2005). Due to their excellence in recording past climatic conditions, lake sediments have been gathering increasing attention of paleomagnetists during the last decades. However, little remains known about the magnetic mineralogy of lake and continental sediments from large igneous provinces, like the DVP, where acidity induced by volcanism may play an additional role in shaping magnetic assemblage of sediments.

A combination of rock magnetic characteristics indicates that sediments of the three studied sections contain a mixture of low, intermediate and high coercivity phases. Based on rock magnetic analyses and microscopic observations, we identified detrital magnetite, titanomagnetite, (titano-) hematite, iron sulphides (pyrrhotite and/or greigite) and secondary magnetite replacing framboidalpyrites in the studied rocks. Goethite may also be present; however, it cannot be reliably detected with the available equipment. Similar magnetic assemblages, with predominant contribution from low-titanium titanomagnetite $\left(\mathrm{T}_{\mathrm{C}}=500-580{ }^{\circ} \mathrm{C}\right)$ and subordinate amount of (titano-) hematite and (titano-) maghemite $\left(\mathrm{T}_{\mathrm{C}}=650-680^{\circ} \mathrm{C}\right)$ have been reported by previous studies of the Deccan basalts (Chenet et al., 2009; Chenet et al., 2008; Vandamme and Courtillot, 1992; Vandamme et al., 1991).

In the Dhapewada and Daïwal River sections, coercivity-dependent properties of sediments vary little with depth and are similar in all lithological varieties, suggesting a uniform ferrimagnetic assemblage. Deccan lava flows and intertrappean sediments share similar S-ratio values, suggesting that the percentage contribution of soft versus hard material is almost the same in both cases. A positive correlation between magnetic susceptibility $(\chi)$ and $\mathrm{Ti}$ content (i.e., inert detrital element), suggests that the iron bearing phases that control the $\chi$ signal are associated with the detrital fraction (Fig. 10). In addition, similarity in $\mathrm{Ti}$ content and exsolution textures of the iron oxide grains 
observed in basalt and lacustrine intertrappean sediments samples (Fig. 8), suggests that the source of magnetic fraction of the sediments is detritus and produced during weathering of the basalts.

Hysteresis-based magnetic grain-size estimates indicate a mixture of single-domain and multidomain grain-sizes or true PSD grain-size (Fig. 4) in all samples. MD magnetite grains were also observed under SEM in the Dhapewada and Podgawan samples (Fig. 7-8). However, characteristic features of biogenic magnetic grains (fossil magnetosomes) have not been detected by high-resolution FORC and IRM acquisition analyses. The absence of magnetofossils, a common magnetic component in recent (Holocene) lacustrine sediments (Kodama et al., 2013 and references therein; Lascu and Plank, 2013; Pan et al., 2005), suggests that environmental conditions in the DVP lakes were unfavourable either to growth of magnetotactic bacteria or to preservation of their magnetosomes.

At the end of the Cretaceous, the DVP was located in subtropical latitudes, at $\sim 24-30^{\circ} \mathrm{S}$ (Chenet et al., 2009; Vandamme et al., 1991), region normally characterized sub-arid to sub-humid conditions (Fig. 11D $)$. However, semi-arid climate conditions in our study area at that time has been inferred by several workers (Khadkikar et al., 1999; Mohabey and Samant, 2005; Mohabey et al., 1993). The contradiction between the expected subhumid conditions and the observed local sub-arid conditions can be reconciled by "mock aridity" effect (Harris and Vancouvering, 1995), when poor soil development on young basaltic bedrocks hampers establishment of vegetation. Without well-developed vegetation cover, magnetic particles released by erosion from the bedrock would have been easily transported to the lake deposition site by wind and fluvial systems (Fig. $11 \mathrm{D}_{2}$ ). The similarity between the sediment and underlying basalt properties (Curie temperatures, coercivity of component 1-2 and morphology of the Ti-bearing iron 
oxides under SEM) of the Dhapewada and Daïwal River sectionsis consistent little modification of the eroded basaltic detritus during transport to the deposition site.

\subsection{Late Phase-2 (Podgawan) sediments}

Unlike the Dhapewada and Daïwal River sediments, composition of which is typical of volcanic areas lakes, with the predominance of detritus released during weathering from basaltic bedrock with minor contribution of iron sulfides (greigite or pyrrhotite and framboidal pyrite) formed in situ, the Podgawan sediments deposited at the end of Phase 2 has distinct lithological features. In particular, the Podgawan sediments are characterized by 1 ) very low $\chi$ values despite their higher terrigenous fraction (clays and shales) content (Fig.10); 2) higher number of CLG components indicating more variable magnetic mineralogy, 3) ubiquitous occurrence of $\mathrm{Fe}-\mathrm{Ca}-\mathrm{Ce}$ vanadates indicative of acid conditions; and 4) unusual lithological variations in the middle part of the section represented by a charcoal-rich level that is capped by a red clay layer containing fossilized bacterial colonies (Fig. 6).

The differences in the sediment compositions between the sections can be related to the difference in clastic source and/or to differing environmental conditions. In order to test so, we normalized our magnetic properties by Titanium contents provided by Fantasia et al. (this volume) for the same set of samples. Ti/Fe ratio are usually indicative of changes in basalt composition and/or of alteration processes (Fe being mobile during weathering/dissolution reactions, while $\mathrm{Ti}$ is not). The magnetic mineralogy of the Deccan basalt (including Ti-bearing iron oxides) showed few variations throughout the volcanic pile (Chenet et al., 2009; Chenet et al., 2008; Vandamme and Courtillot, 1992; Vandamme et al., 1991). In addition, detailed stratigraphy based on whole-rock 
geochemistry for a $1200 \mathrm{~m}$ sequence of basaltic lava flows in the Western Ghats escarpment near Mahabaleshwar showed little variations of TiO2 content (1-4\%wt) throughout the whole volcanic pile (Cox and Hawkesworth, 1985). Therefore, we consider that a change in the source composition is not likely in our case and variations in $\mathrm{Ti}$ content should rather reflect changes in alteration processes (weathering, dissolution). Such interpretations is corroborated by high Ti/Al ratio and high CIA-K index observed in the Podgawan section (Fantasia et al., this volume) that are indicative of high weathering rates and/or severe dissolution processes. Normalized for titanium (i.e., detrital fraction content), Podgawan sediments have $\sim$ order of magnitude lower susceptibility (Fig. 11A) compared to the Daïwal River and the Dhapewada sections. Lower SIRM values of the component 2 (identified as magnetite) are also indicative of a relative decrease in ferrimagnetic mineral content at Podgawan (Fig. 11B). Reductive dissolution of iron oxides under anoxic conditions, a common process that can lead to decrease in concentration of magnetic phases, is not likely to explain the susceptibility variations between the three sections, because organic matter content - the main factor controlling reductive dissolution - is similar in all three sections (Fantasia et al., this volume). Instead, we suggest that the low $\chi$ values result from acidic dissolution of iron oxides.

As environmental impact of volcanism depends on the volume and rate of eruptions and on amount of acid aerosol released,towards the end of the most voluminous Phase 2, cumulative effect of Deccan volcanic activity has likely reached its maximum. The consequence of massive volatile releases is the lowering $\mathrm{pH}$ of meteoric precipitation and runoff in the catchment area(Blong, 1984), leading to lowering $\mathrm{pH}$ of the lake water. Increased acidity would have strong effect on concentration and average grain size of detrital iron oxides. Under present-day conditions $\left(\mathrm{pH}_{\text {rain }}=5.6\right)$, sand-size 
magnetite grains have very long residence time at the Earth surface, in excess of $10^{7}$ years(White et al., 1994). Geochemical modelling, however, suggest that at meteoric $\mathrm{pH}$ of 3.3-4.3, comparable with the modern $\mathrm{pH}_{\text {rain }}$ at Mount Etna (Calabrese et al. (2011), magnetite dissolves completely in $\sim 30-60,000$ yrs (Font et al., 2014). Increased acidity of aqueous environments have been previously proposed as an explanation for the decrease in concentration of magnetic minerals in pelagic Panthalassa sediments at the Triassic-Jurassic boundary (Abrajevitch et al., 2013), and continental shelf sediments deposited prior to Cretaceous-Paleogene boundary (Font and Abrajevitch, 2014; Font et al., 2014; Font et al., 2011). Similar process likely operated within the Deccan Volcanic Province.

Partial dissolution of detrital magnetite that either modified grain-size distributions and/or provided iron source for precipitation of authigenic magnetic phases, likely resulted in additional CLG components observed in IRM acquisition curves of these sediments (Fig. 11B). Higher Chemical alteration index (CIA) values of the Podgawan sediments (Fantasia et al.,this volume) support the connection between the environmental (weathering intensity) and mineral assemblage changes.

Ubiquitous Ca-Fe-rich vanadates in the Podgawan sediments offer another line of evidence for acidity change. In natural waters, the chemistry of vanadium is dominated by $\mathrm{V}(\mathrm{IV})$ and $\mathrm{V}(\mathrm{V})$ species.Dissolved vanadate $(\mathrm{V}(\mathrm{V}))$ predominates in oxic water and is reduced to vanadyl ion (V(IV)) by organic compounds or by dissolved $\mathrm{H}_{2} \mathrm{~S}$ (Breit and Wanty, 1991; Morford and Emerson, 1999; Wanty et al., 1990; Wehrli and Stumm, 1989). Reduction ofV(IV)by $\mathrm{H}_{2} \mathrm{~S}$, followed by hydrolysis and precipitation of $\mathrm{V}(\mathrm{III})$ in iron oxides (e.g. montroseite), is considered to be the most likely vanadium oreformingprocess(Wanty et al., 1990). During the deposition of the Podgawan sediments at the end of Deccan Phase 2 eruptions, large amounts of vanadium would have been 
available from enhanced weathering of basaltichost (Wanty et al., 1990), while $\mathrm{H}_{2} \mathrm{~S}$ would have been supplied by volcanic aerosols.

An abrupt lithofacies change in the middle of the Podgawan sequence, a black charcoalrich bed cupped by a red clay layer (Fig. $11 \mathrm{D}_{3}$ ), provides another glimpse of environmental conditions at the lake catchment area. The reversible behavior of the thermomagnetic heating/cooling curves of the sample from the charcoal (Fig. 3d) suggests that the detrital material have been burnt at temperatures higher than the Curie point of magnetite $\left(580^{\circ} \mathrm{C}\right)$. Previous heating explanation is consistent with allogenic origin and degradation by wildfire of organic matter in this level proposed by Fantasia et al. (this volume).

The red clay layer that overlies the charcoal-rich bed is characterized by high amount of magnetite (blue CLG in Fig. 11B) reflected in $\chi$ peak (Fig. 6), and slightly lower S-ratio values that are indicative of a higher contribution fromhigh coercivity magnetic minerals (hematite/goethite). Higher content of pigmentary hematite can account for the distinct red color of the layer, although abundant vanadium species observed in this layer may also contribute to coloration, since vanadium generally forms orange-red soluble complexes in acid media (Evans, 1959).

The distinct feature of the red layer is abundant "bubble-like" and "honeycomb" structures (Fig. 9 f-i). These structures are likely to be fossilized remains of bacterial colonies, either of lithotrophic Fe-oxidizing bacteria that use iron as energy sourcethrough oxidation of $\mathrm{Fe}^{2+}$ to $\mathrm{Fe}^{3+}$ (Emerson et al., 2010), or of phototrophic bacteria that have been mineralized and encrusted in iron oxides. While we cannot offer an unambiguous explanation for these structures, we note that they are found only in the red clay layer. The unique occurrence suggests that unusual environmental conditions, 
particularly favorable either to bacterial activity, or to enhanced preservation of bacterial remains, existed during the deposition of the layer.

Overall, a combination of characteristic features of the Podgawan sediments, such as low titanium-normalized susceptibility values, diverse magnetic phases and presence of vanadates are best explained by acidic environment in the lake; while the charcoal and red clay beds suggest dramatic biotic events, such as wildfires and bacterial blooms, in the lake catchment basin. The change in acidity that drove the observed lithological changes had likely resulted from cumulative effect of volcanic aerosols release during the Deccan Phase-2. Our interpretation of lithological characteristics of the Podgawan sediments as acidity-related opens new perspectives for evaluation ofthe impact of Deccan-induced acid rains on biota and environment at the end of the Cretaceous.

\section{Conclusion}

Results of our study indicate that mineral assemblages of the lake sediments deposited during earlier stages of the Deccan Phase 2 eruptions (the Dhapewada and Daïwal River sections) differ significantly from those deposited at the final stages (the Podgawan section). In addition to siliceous fraction of sediments, the Dhapewada and Daïwal River sections contain detrital iron oxides with magnetite-ilmenite exsolution features, similar to those of basaltic source rocks, and some authigenic iron sulfides (predominantly framboidal pyrite with minor pyrrhotite and or greigite).

The Podgawan section sediments are characterized by 1) very low content of magnetic phases (indicated by low values of magnetic susceptibility normalized for detrital fraction content); 2) more variable domain state/grain size coercivity spectra proxies (indicated by higher number of fitted IRM acquisition components); 3) ubiquitous presence of Fe-Ca-Ce vanadates; and 4) unusual lithological variations in the middle 
part of the section (represented by a charcoal-rich level that is capped by a red clay layer containing fossilized remains of bacterial colonies).

The presence of vanadates provides strong evidence for acidic conditions in the lake catchment area, as their formation require high concentration of vanadium (supplied by enhanced weathering of basaltic rocks) and $\mathrm{H}_{2} \mathrm{~S}$ (provided by volcanic aerosols). Acidic conditions (that facilitate partial dissolution of oxides leading to changing grain-size distribution of ferrimagnetic population, as well as providing a source of iron for precipitation of new authigenic phases) also accounts for the observed loss of detrital ferrimagnetic iron oxides and variable magnetic components. Dramatic biotic events, wildfires and bacterial blooms, recorded in distinct charcoal-rich and red clay beds of the Podgawan section, may also indicate deterioration of environmental conditions in the lake catchment basin. We suggest that the increased acidity during the deposition of the Podgawan sequence is due to cumulative effects of volcanic aerosols release during the Deccan Phase 2 eruptions.

The observed in the Podgawan sediments combination of features, such as a decrease in magnetic mineral content accompanied with changes in coercivity distributions and the presence of vanadates, may be used to identify episodes of increased acidity in the geological record. Our results also contribute to understanding of local vs. global effects of the Deccan volcanism.

\section{FIGURE CAPTIONS}

Figure 1. Geological settings of the studied area. A, B) The Deccan Volcanic Province (India) and the location of the studied area; C) Block diagram showing the stratigraphic position of the studied continental and lacustrines deposits in relation to the Deccan Phase 1, 2 and 3 (modified from Fantasia et al., this issue). 
Figure 2. Magnetic ( $\chi$, IRM-CLG parameters and FORC diagram) data of the Daïwal River sediments interstratified within Deccan Phase-1 basalts. SIRM is the IRM at saturation, while $\mathrm{B}_{1 / 2}$ corresponds to the component coercivity. S-ratio corresponds to IRM $_{-0.3 \mathrm{~T}} / \mathrm{IRM}_{1 \mathrm{~T}}$. The lower and upper basalt units share the same $\mathrm{B}_{1 / 2}$ and $\mathrm{S}$-ratio values as the lacustrine sediments suggesting that most of the iron oxides contained in the latter are inherited from the weathering of the underlying basalts.

Figure 3. High-temperature dependence of low field mass specific magnetic susceptibility of the lacustrine sediments under study: A) Daiwal River, B) Dhapewada, C) Stepwise partial heating-cooling runs of sample Dhap10, and D) Podgawan.

Figure 4. Day plot (Day et al., 1977)for 14 representative sediment samples from the Dhapewada, Daiwal River and Podgawan sections, including the lower and upper basalts of the Daiwal River (squares). The theoretical mixing curves for magnetite of Dunlop $(2000 \mathrm{a}, \mathrm{b})$ are shown for comparison. Trends of remagnetized carbonates are also shown. Most of the samples follow the theoretical mixing curves SD+MD, showing a variable proportion of MD particles from $<40 \%$ in the Podgawan sediments up to $40 \%$ in the Dhapewada and Daiwal River sediments.

Figure 5. Magnetic ( $\chi, \mathrm{Kfd}, \mathrm{IRM}-\mathrm{CLG}$ parameters, S-ratio and FORC diagram) data of the Dhapewada sediments interstratified within Deccan Phase-1 basalts. SIRM is the IRM at saturation, while $\mathrm{B}_{1 / 2}$ corresponds to the component coercivity.Sratiocorresponds to $-\mathrm{IRM}_{-0.3 \mathrm{~T}} / \mathrm{IRM}_{1 \mathrm{~T}}$. 
Figure 6. Magnetic ( $\chi, \mathrm{Kfd}$, IRM-CLG parameters, S-ratio and FORC diagram) data of the Podgawan sediments. SIRM is the IRM at saturation, while $\mathrm{B}_{1 / 2}$ corresponds to the component coercivity.S-ratio corresponds to -IRM-0.3T $/ \mathrm{IRM}_{1 \mathrm{~T}}$.

Figure 7.Scanning Electron Microscopy (SEM) observation coupled to Energy Dispersive Spectra (EDS) analysis of the Dhapewada (Dhap3, Dhap16 and Dhap17) samples. A) Framboids of iron oxide crystals (magnetite from pyrite conversion?). B) SEM photograph and EDS compositional mapping of a coarse $(>20 \mu \mathrm{m})$ Ti-bearing iron oxide (titanomagnetite?) with dissolutionfeatures (white arrows). C) Fine $(\sim 10 \mu \mathrm{m})$ and eroded (detrital) titanomagnetites. D) Euhedral magnetite spinel. E) Iron oxides (or hydroxydes?) without Ti. F) Anhedral crystal of iron sulphide.

Figure 8. Scanning Electron Microscopy observation coupled to Energy Dispersive Spectra analysis of the iron oxides of the Podgawan samples. A) The lower basalt (POB13) contains small $(\sim 10 \mu \mathrm{m})$ iron oxides with cubic-like structure and subhedral shapes resembling to magnetite. Ti is either absent or in moderate amounts; B) Similar Ti-bearing iron oxide observed in the coal-rich sediment (POA14); C) Presence of magnetite with exsolution textures indicate an igneous (detrital) origin for the iron oxides; D) Idem for larger $(\sim 100 \mu \mathrm{m})$ ilmenite grains with exsolution features; E) Pyrite framboid transformed in magnetite; F) Semi-hexagonal and plate-like iron sulphur (pyrrhotite); G) Sylvite $(\mathrm{KCl})$ is frequently observed in the Podgawan samples and present detrital aspects with grain size of $\sim 5 \mu \mathrm{m} ; \mathrm{H})$ An isolated organic compound 
(Myccorhiza fungi?) is locally observed in POB11. The flattened shape is due to vacuum.

Figure 9.Scanning Electron Microscopy observation coupled to Energy Dispersive Spectra analysis of Podgawan samples (suite). A) Large $(\sim 100 \mu \mathrm{m})$ aggregates of Fevanadates. B) The vanadates crystals also contain $\mathrm{Ca}$ and $\mathrm{Ce}$ as other constituent elements; C-D) In sample POA14 (coal), vanadate crystals have a disk-like morphology with grain size inferior to $1 \mu \mathrm{m}$; E) Crust of iron oxide/hydroxide are ubiquitously observed in the red clay sample (POA16). Needle-fiber calcite are also ubiquitously encountered and present well crystallized shape of $10-20 \mu \mathrm{m}$ long and less than $1 \mu \mathrm{m}$ in diameter; F) Under higher resolution, the thickness of the crust is less than $1 \mu \mathrm{m}$ and coat the surface of clay materials; G) "bubble structure" systematically associated to iron oxide-rich crust show a very well-organized structures similar to bacterial chains; H) Photograph showing that the tiny iron microspheres originated from the bubble structure; I) iron oxides showing dissolution features or suggesting a bacterial origin.

Figure 10.Correlation between mass-specific magnetic susceptibility andTi content (in $\% \mathrm{wt}$ ). The positive correlation observed in all studied sections suggest a detrital origin for the main magnetic carriers.

Fig. 11.Conceptual model of environmental lacustrine and continental settings during Deccan Phase 2. (A) $\chi\left(10^{-6} \mathrm{~m}^{3} / \mathrm{kg}\right)$ normalized by Ti-content $(\mathrm{wt} \%)$ is drastically lower in the Podgawan section, suggesting dissolution effect linked to acid conditions. (B) Number of IRM components (illustrated here by the cumulative Gaussian curves) are 
systematically higher in the Podgawan samples suggesting additional input of iron oxides and/or active mineralogical transformations linked to higher weathering conditions. (C) Chemical Alteration Index (CIA) modified from Fantasia et al. (this volume). (D) Possible scenario showing, from the bottom to the top, $\left(D_{1}\right)$ hypothetical lacustrine settings of sub-tropical climate with the potential source of iron oxides (pedogenic, aeolian, detrital, biogenic). $\left(\mathrm{D}_{2}\right)$ In contrast, the Daïwal River and the Dhapewada lakes under study are devoid of biogenicmagnetic particles. $\left(\mathrm{D}_{3}-\mathrm{D}_{4}\right)$ At the end of Phase 2 eruptions, the cumulative effect of greenhouse gases and acid aerosol $\left(\mathrm{H}_{2} \mathrm{~S}\right)$ releases would have led to drastic environmental changes including wildfires (POA14) and acid rains (POA16). Acidification in the sedimentary record is evidenced by ubiquitous crystallization of iron vanadates and acidic iron oxide dissolution (very low $\chi)$.

Table 1. Lithofacies, distance from the base of the section, mass of the samples and magnetic parameters obtained from the cumulative log-Gaussian analysis of the isothermal remanent magnetization (IRM) curves. S ratio is calculated by using the formula - IRM $_{-0.3 \mathrm{~T}} / \mathrm{IRM}_{1 \mathrm{~T}}$; Mass SIRM is the mass normalized saturation isothermal remanent magnetization; $\mathrm{B}_{1 / 2}$ is the mean coercivity in $\mathrm{mT}$; $\mathrm{DP}$ is the Dispersion parameter and $\%$ is the percentage of remanence contribution.

\section{ACKNOWLEDGEMENTS}

Funding was provided by FCT (ref. PTDC/CTE-GIX/117298/2012). We thank Celia Lee and Ana Sousa for technical and administrative supply, David Emerson (Bigelow Laboratory for Ocean Sciences, USA) for helpful discussion about iron-oxidizing 
bacteria. We are grateful to the Guest Associate Editor Wolfram Michael Kürschner and

to the anonymous referees for the attention and for the helpful comments.

\section{REFERENCES}

Abrajevitch, A., Hori, R.S., Kodama, K., 2013. Rock magnetic record of the TriassicJurassic transition in pelagic bedded chert of the Inuyama section, Japan. Geology doi:10.1130/G34343.1.

Adatte, T., Keller, G., 2013. Multiproxy Evidence of main Deccan Traps Pulse near the Cretaceous-Tertiary Boundary. Special Publication Geological Society of India 1, $1-15$.

Basu, A., Molinaroli, E., 1989. Provenance Characteristics of Detrital Opaque Fe-Ti Oxide Minerals. J Sediment Petrol 59, 922-934.

Blong, R.J., 1984. Volcanic hazard - A sourcebook on the effects of eruptions. Academic Press, Australia, 424 p. .

Breit, G.N., Wanty, R.B., 1991. Vanadium Accumulation in Carbonaceous Rocks - a Review of Geochemical Controls during Deposition and Diagenesis. Chemical Geology 91, 83-97.

Brothers, L.A., Engel, M.H., Elmore, R.D., 1996. The late diagenetic conversion of pyrite to magnetite by organically complexed ferric iron. Chemical Geology 130, $1-14$.

Calabrese, S., Aiuppa, A., Allard, P., Bagnato, E., Bellomo, S., Brusca, L., D'Alessandro, W., Parello, F., 2011. Atmospheric sources and sinks of volcanogenic elements in a basaltic volcano (Etna, Italy). Geochim Cosmochim Ac 75, 7401-7425.

Channell, J.E.T., Mccabe, C., 1994. Comparison of Magnetic Hysteresis Parameters of Unremagnetized and Remagnetized Limestones. Journal of Geophysical Research-Solid Earth 99, 4613-4623.

Chenet, A.L., Courtillot, V., Fluteau, F., Gerard, M., Quidelleur, X., Khadri, S.F.R., Subbarao, K.V., Thordarson, T., 2009. Determination of rapid Deccan eruptions across the Cretaceous-Tertiary boundary using paleomagnetic secular variation: 2 . Constraints from analysis of eight new sections and synthesis for a 3500-m-thick composite section. Journal of Geophysical Research-Solid Earth 114.

Chenet, A.L., Fluteau, F., Courtillot, V., Gerard, M., Subbarao, K.V., 2008. Determination of rapid Deccan eruptions across the Cretaceous-Tertiary boundary using paleomagnetic secular variation: Results from a 1200-m-thick section in the Mahabaleshwar escarpment. Journal of Geophysical Research-Solid Earth 113.

Chenet, A.L., Quidelleur, X., Fluteau, F., Courtillot, V., Bajpai, S., 2007. K-40-Ar-40 dating of the Main Deccan large igneous province: Further evidence of KTB age and short duration. Earth Planet Sc Lett 263, 1-15.

Courtillot, V., Besse, J., Vandamme, D., Montigny, R., Jaeger, J.J., Cappetta, H., 1986. Deccan Flood Basalts at the Cretaceous Tertiary Boundary. Earth Planet Sc Lett 80, 361-374.

Courtillot, V., Fluteau, F., 2014. A review of the embedded time scales of fl ood basalt volcanism with special emphasis on dramatically short magmatic pulses. in 
Keller, G., and Kerr, A., eds., Volcanism, Impacts, and Mass Extinctions: Causes and Effects: Geological Society of America Special Paper 505, p. 1-XXX,

doi:10.1130/2014.2505(15).

Courtillot, V., Gallet, Y., Rocchia, R., Feraud, G., Robin, E., Hofmann, C., Bhandari, N., Ghevariya, Z.G., 2000. Cosmic markers, Ar-40/Ar-39 dating and paleomagnetism of the KT sections in the Anjar Area of the Deccan large igneous province. Earth Planet Sc Lett 182, 137-156.

Courtillot, V., Vandamme, D., Besse, J., Jaeger, J.J., 1988. Deccan Volcanism at the Cretaceous-Tertiary Boundary. Chemical Geology 70, 118-118.

Courtillot, V.E., Renne, P.R., 2003. On the ages of flood basalt events. Cr Geosci 335, 113-140.

Cox, K.G., Hawkesworth, C.J., 1985. Geochemical Stratigraphy of the Deccan Traps at Mahabaleshwar, Western Ghats, India, with Implications for Open System Magmatic Processes. Journal of Petrology 26, 355-377.

Day, R., Fuller, M., Schmidt, V.A., 1977. Hysteresis Properties of Titanomagnetites Grain-Size and Compositional Dependence. Physics of the Earth and Planetary Interiors 13, 260-267.

Deconinck, J.F., Debrabant, P., 1985. Clay-Minerals Diagenesis in the Sub-Alpine Area - Respective Influences of Lithology, Burial Diagenesis and Tectonic Overload. Rev Geol Dyn Geogr 26, 321-330.

Dunlop, 2002a. Theory and application of the Day plot (M-rs/M-s versus H-cr/H-c) 1 . Theoretical curves and tests using titanomagnetite data. Journal of Geophysical Research-Solid Earth 107.

Dunlop, D., Özdemir, Ö., 1997. Rock Magnetism: Fundamentals and Frontiers. Cambridge University Press, Cambridge.

Dunlop, D.J., 2002b. Theory and application of the Day plot (M-rs/M-s versus H-cr/Hc) 2. Application to data for rocks, sediments, and soils. Journal of Geophysical Research-Solid Earth 107.

Emerson, D., Fleming, E.J., McBeth, J.M., 2010. Iron-Oxidizing Bacteria: An Environmental and Genomic Perspective. Annu Rev Microbiol 64, 561-583.

Evans, H.T., 1959. The crystal chemistry and mineralogy of vanadium. in Geochemistry and Mineralogy of the Colorado Plateau Uranium Ores, eds. by R.M: Garrels and E.S. Larsen, 91-102.

Ferry, S., Cotillon, P., Rio, M., 1983. Increasing Diagenesis of Clay-Minerals in Isochronous Levels of Valanginian Limestone - Marl Alternations of the Vocontian Trough - Geographic Zonation. Cr Acad Sci Ii 297, 51-\&.

Font, E., Abrajevitch, A., 2014. Paleoenvironmental signature of the Deccan Phase-2 eruptions. Frontiers in Earth Sciences.

Font, E., Fabre, S., Nedelec, A., Adatte, T., Keller, G., Veiga-Pires, C., Ponte, J., Mirão, J., Khozyem, H., Spangenberg, J., 2014. Atmospheric halogen and acid rains during the main phase of Deccan eruptions: Magnetic and mineral evidence. in Keller, G., and Kerr, A.C., eds., Volcanism, Impacts, and Mass Extinctions: Causes and Effects: Geological Society of America Special Paper 505, 1-16.

Font, E., Nedelec, A., Ellwood, B.B., Mirao, J., Silva, P.F., 2011. A new sedimentary benchmark for the Deccan Traps volcanism? Geophysical Research Letters 38.

Font, E., Trindade, R.I.F., Nedelec, A., 2006. Remagnetization in bituminous limestones of the Neoproterozoic Araras Group (Amazon craton): Hydrocarbon maturation, burial diagenesis, or both? Journal of Geophysical Research-Solid Earth 111. 
Gertsch, B., Keller, G., Adatte, T., Garg, R., Prasad, V., Berner, Z., Fleitmann, D., 2011. Environmental effects of Deccan volcanism across the Cretaceous-Tertiary transition in Meghalaya, India. Earth Planet Sc Lett 310, 272-285.

Ghosh, P., Sayeed, M.R.G., Islam, R., Hundekari, S.M., 2006. Inter-basaltic clay (bole bed) horizons from Deccan traps of India: Implications for palaeo-weathering and palaeo-climate during Deccan volcanism. Palaeogeography Palaeoclimatology Palaeoecology 242, 90-109.

Harris, J., Vancouvering, J., 1995. Mock Aridity and the Paleoecology of Volcanically Influenced Ecosystems. Geology 23, 593-596.

Harrison, R.J., Feinberg, J.M., 2008. FORCinel: An improved algorithm for calculating first-order reversal curve distributions using locally weighted regression smoothing. Geochemistry, Geophysics, Geosystems 9, Q05016.

Heslop, D., Dekkers, M.J., Kruiver, P.P., van Oorschot, I.H.M., 2002. Analysis of isothermal remanent magnetization acquisition curves using the expectationmaximization algorithm. Geophys J Int 148, 58-64.

Heslop, D., McIntosh, G., Dekkers, M.J., 2004. Using time- and temperature-dependent Preisach models to investigate the limitations of modelling isothermal remanent magnetization acquisition curves with cumulative log Gaussian functions. Geophys J Int 157, 55-63.

Hirt, A.M., Banin, A., Gehring, A.U., 1993. Thermal Generation of Ferromagnetic Minerals from Iron-Enriched Smectites. Geophys J Int 115, 1161-1168.

Horng, C.S., Roberts, A.P., 2006. Authigenic or detrital origin of pyrrhotite in sediments?: Resolving a paleomagnetic conundrum. Earth Planet Sc Lett 241, 750-762.

Jackson, M., 1990. Diagenetic Sources of Stable Remanence in Remagnetized Paleozoic Cratonic Carbonates - a Rock Magnetic Study. Journal of Geophysical Research-Solid Earth and Planets 95, 2753-2761.

Jay, A.E., Mac Niocaill, C., Widdowson, M., Self, S., Turner, W., 2009. New palaeomagnetic data from the Mahabaleshwar Plateau, Deccan Flood Basalt Province, India: implications for the volcanostratigraphic architecture of continental flood basalt provinces. J Geol Soc London 166, 13-24.

Jay, A.E., Widdowson, M., 2008. Stratigraphy, structure and volcanology of the SE Deccan continental flood basalt province: implications for eruptive extent and volumes. J Geol Soc London 165, 177-188.

Keller, G., 2014. Deccan volcanism, the Chicxulub impact, and the end-Cretaceous mass extinction: Coincidence? Cause and effect? in Keller, G., and Kerr, A.C., eds., Volcanism, Impacts, and Mass Extinctions:Causes and Effects: Geological Society of America Special Paper 505, 57-90.

Keller, G., Adatte, T., Bajpai, S., Mohabey, D.M., Widdowson, M., Khosla, A., Sharma, R., Khosla, S.C., Gertsch, B., Fleitmann, D., Sahni, A., 2009. K-T transition in Deccan Traps of central India marks major marine Seaway across India. Earth Planet Sc Lett 282, 10-23.

Keller, G., Adatte, T., Bhowmick, P.K., Upadhyay, H., Dave, A., Reddy, A.N., Jaiprakash, B.C., 2012. Nature and timing of extinctions in Cretaceous-Tertiary planktic foraminifera preserved in Deccan intertrappean sediments of the KrishnaGodavari Basin, India. Earth Planet Sc Lett 341, 211-221.

Keller, G., Bhowmick, P.K., Upadhyay, H., Dave, A., Reddy, A.N., Jaiprakash, B.C., Adatte, T., 2011. Deccan Volcanism Linked to the Cretaceous-Tertiary Boundary Mass Extinction: New Evidence from ONGC Wells in the Krishna-Godavari Basin. J Geol Soc India 78, 399-428. 
Khadkikar, A.S., Sant, D.A., Gogte, V., Karanth, R.V., 1999. The influence of Deccan volcanism on climate: insights from lacustrine intertrappean deposits, Anjar, western India. Palaeogeography Palaeoclimatology Palaeoecology 147, 141-149.

Kodama, K.P., Moeller, R.E., Bazylinski, D.A., Kopp, R.E., Chen, A.P., 2013. The mineral magnetic record of magnetofossils in recent lake sediments of Lake Ely, PA. Global Planet Change 110, 350-363.

Krs, M., Krsova, M., Pruner, P., Zeman, A., Novak, F., Jansa, J., 1990. A Petromagnetic Study of Miocene Rocks Bearing Microorganic Material and the Magnetic Mineral Greigite (Sokolov and Cheb Basins, Czechoslovakia). Physics of the Earth and Planetary Interiors 63, 98-112.

Kruiver, P.P., Dekkers, M.J., Heslop, D., 2001. Quantification of magnetic coercivity components by the analysis of acquisition curves of isothermal remanent magnetisation. Earth Planet Sc Lett 189, 269-276.

Kubler, B., Jaboyedoff, M., 2000. Illite crystallinity. Cr Acad Sci Ii A 331, 75-89.

Lascu, I., Plank, C., 2013. A new dimension to sediment magnetism: Charting the spatial variability of magnetic properties across lake basins. Global Planet Change 110, 340-349.

Liu, Q.S., Roberts, A.P., Larrasoana, J.C., Banerjee, S.K., Guyodo, Y., Tauxe, L., Oldfield, F., 2012. Environmental Magnetism: Principles and Applications. Reviews of Geophysics 50.

Mohabey, D.M., Samant, B., 2005. Lacustrine facies association of a Maastrichtian lake (Lameta Formation) from Deccan volcanic terrain, central India: Implications to depositional history, sediment cyclicity and climates. Gondwana Geological Magazine Special Issue, vol. 8, 37-52.

Mohabey, D.M., Udhoji, S.G., Verma, K.K., 1993. Paleontological and Sedimentological Observations on Nonmarine Lameta Formation (Upper Cretaceous) of Maharashtra, India - Their Paleoecological and Paleoenvironmental Significance. Palaeogeography Palaeoclimatology Palaeoecology 105, 83-94.

Morad, S., Aldahan, A.A., 1986. Alteration of Detrital Fe-Ti Oxides in SedimentaryRocks. Geol Soc Am Bull 97, 567-578.

Morford, J.L., Emerson, S., 1999. The geochemistry of redox sensitive trace metals in sediments. Geochim Cosmochim Ac 63, 1735-1750.

Pan, Y.X., Petersen, N., Davila, A.F., Zhang, L.M., Winklhofer, M., Liu, Q.S., Hanzlik, M., Zhu, R.X., 2005. The detection of bacterial magnetite in recent sediments of Lake Chiemsee (southern Germany). Earth Planet Sc Lett 232, 109-123.

Pike, C.R., Roberts, A.P., Verosub, K.L., 1999. Characterizing interactions in fine magnetic particle systems using first order reversal curves. J Appl Phys 85, 66606667.

Roberts, A.P., 1995. Magnetic-Properties of Sedimentary Greigite (Fe3s4). Earth Planet Sc Lett 134, 227-236.

Roberts, A.P., Chang, L.A., Rowan, C.J., Horng, C.S., Florindo, F., 2011. Magnetic Properties of Sedimentary Greigite (Fe3s4): An Update. Reviews of Geophysics 49.

Roberts, A.P., Heslop, D., Zhao, X., Pike, C.R., 2014. Understanding fine magnetic particle systems through use of first-order reversal curve diagrams. Reviews of Geophysics 52.

Roberts, A.P., Pike, C.R., Verosub, K.L., 2000. First-order reversal curve diagrams: A new tool for characterizing the magnetic properties of natural samples. Journal of Geophysical Research-Solid Earth 105, 28461-28475. 
Roberts, A.P., Weaver, R., 2005. Multiple mechanisms of remagnetization involving sedimentary greigite (Fe3S4). Earth Planet Sc Lett 231, 263-277.

Robertson, D.J., France, D.E., 1994. Discrimination of remanence-carrying minerals in mixtures, using Isothermal Remanent Magnetization acquisition curves. Physics of the Earth and Planetary Interiors 82, 223-234.

Rochette, P., Fillion, G., Mattei, J.L., Dekkers, M.J., 1990. Magnetic Transition at 3034-Kelvin in Pyrrhotite - Insight into a Widespread Occurrence of This Mineral in Rocks. Earth Planet Sc Lett 98, 319-328.

Samant, B., Mohabey, D.M., 2005. Response of flora to Deccan volcanism: a case study from Nand-Dongargaon basin of Maharashtra, implications to environment and climate. Gondwana Geological Magazine 8, 151-164.

Samant, B., Mohabey, D.M., 2009. Palynoflora from deccan volcano-sedimentary sequence (Cretaceous-Palaeogene transition) of central India: implications for spatio-temporal correlation. J Biosciences 34, 811-823.

Samant, B., Mohabey, D.M., 2014. Deccan volcanic eruptions and their impact on flora: Palynological evidence. in Keller, G., and Kerr, A.C., eds., Volcanism, Impacts, and Mass Extinctions:Causes and Effects: Geological Society of America Special Paper 505, 171-191.

Samant, B., Mohabey, D.M., Kapgate, D.K., 2008. Palynofloral record from Singpur intertrappean, Chhindwara District, Madhya Pradesh: Implication for Late Cretaceous stratigraphic correlation and resolution. J Geol Soc India 71, 851-858.

Schoene, B., Samperton, K.M., Eddy, M.P., Keller, G., Adatte, T., Bowring, S.A., Khadri, S.F.R., Gertsch, B., 2015. U-Pb geochronology of the Deccan Traps and relation to the end-Cretaceous mass extinction. Science 347 182-184.

Self, S., Blake, S., Sharma, K., Widdowson, M., Sephton, S., 2008. Sulfur and chlorine in Late Cretaceous Deccan magmas and eruptive gas release. Science 319, 16541657.

Self, S., Widdowson, M., Thordarson, T., Jay, A.E., 2006. Volatile fluxes during flood basalt eruptions and potential effects on the global environment: A Deccan perspective. Earth Planet Sc Lett 248, 518-532.

Shrivastava, J.P., Ahmad, M., Srivastava, S., 2012. Microstructures and compositional variation in the intravolcanic bole clays from the eastern Deccan volcanic province: Palaeoenvironmental implications and duration of volcanism. J Geol Soc India 80, 177-188.

Sial, A.N., Lacerda, L.D., Ferreira, V.P., Frei, R., Marquillas, R.A., Barbosa, J.A., Gaucher, C., Windmoller, C.C., Pereira, N.S., 2013. Mercury as a proxy for volcanic activity during extreme environmental turnover: The CretaceousPaleogene transition. Palaeogeography Palaeoclimatology Palaeoecology 387, 153-164.

Suk, D., Peacor, D.R., Vandervoo, R., 1990. Replacement of Pyrite Framboids by Magnetite in Limestone and Implications for Paleomagnetism. Nature 345, 611613.

Suk, D.W., Vandervoo, R., Peacor, D.R., 1993. Origin of Magnetite Responsible for Remagnetization of Early Paleozoic Limestones of New-York-State. Journal of Geophysical Research-Solid Earth 98, 419-434.

Sun, W.W., Jackson, M., 1994. Scanning Electron-Microscopy and Rock Magnetic Studies of Magnetic Carriers in Remagnetized Early Paleozoic Carbonates from Missouri. Journal of Geophysical Research-Solid Earth 99, 2935-2942.

Thompson, R., Oldfield, F., 1986. Environmental Magnetism. Allen and Unwin, London 1986. pp. 227. 
Trindade, R.I.F., D'Agrella, M.S., Babinski, M., Font, E., Neves, B.B.B., 2004. Paleomagnetism and geochronology of the Bebedouro cap carbonate: evidence for continental-scale Cambrian remagnetization in the Sao Francisco craton, Brazil. Precambrian Res 128, 83-103.

Vandamme, D., Courtillot, V., 1992. Paleomagnetic Constraints on the Structure of the Deccan Traps. Physics of the Earth and Planetary Interiors 74, 241-261.

Vandamme, D., Courtillot, V., Besse, J., Montigny, R., 1991. Paleomagnetism and AgeDeterminations of the Deccan Traps (India) - Results of a Nagpur-Bombay Traverse and Review of Earlier Work. Reviews of Geophysics 29, 159-190.

Wang, X.S., Lovlie, R., Zhao, X.Y., Yang, Z.Y., Jiang, F.C., Wang, S.B., 2010. Quantifying ultrafine pedogenic magnetic particles in Chinese loess by monitoring viscous decay of superparamagnetism. Geochemistry Geophysics Geosystems 11.

Wanty, R.B., Goldhaber, M.B., Northrop, H.R., 1990. Geochemistry of Vanadium in an Epigenetic, Sandstone-Hosted Vanadium-Uranium Deposit, Henry Basin, Utah. Econ Geol Bull Soc 85, 270-284.

Ward, P.L., 2009. Sulfur dioxide initiates global climate change in four ways. Thin Solid Films 517, 3188-3203.

Wehrli, B., Stumm, W., 1989. Vanadyl in Natural-Waters - Adsorption and Hydrolysis Promote Oxygenation. Geochim Cosmochim Ac 53, 69-77.

Westall, F., 1999. The nature of fossil bacteria: A guide to the search for extraterrestrial life. J Geophys Res-Planet 104, 16437-16451.

White, A.F., Peterson, M.L., Hochella, M.F., 1994. Electrochemistry and Dissolution Kinetics of Magnetite and Ilmenite. Geochim Cosmochim Ac 58, 1859-1875.

Widdowson, M., Walsh, N.J., Subbarao, K.V., 1997. The geochemistry of Indian bole horizons: palaeoenvironmental implications of Deccan intravolcanic palaeosurfaces. The Geological Society of London, Special Publications 120, 269281.

Wignall, P.B., 2001. Large igneous provinces and mass extinctions. Earth-Science Reviews 53, 1-33. 

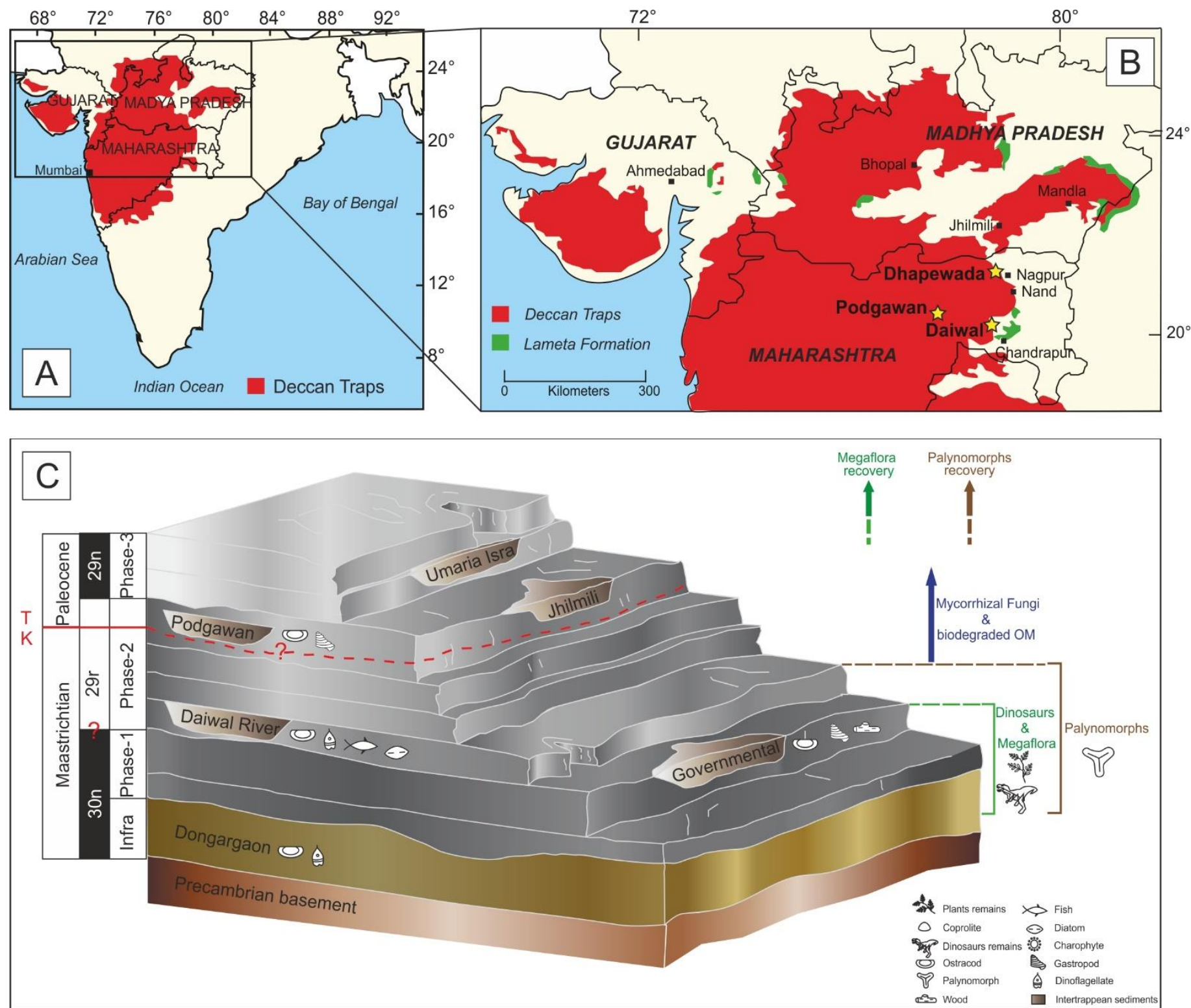

Figure 1. Geological settings of the studied area. A, B) The Deccan Volcanic Province (India) and the location of the studied area; C) Block diagram showing the stratigraphic position of the studied continental and lacustrines deposits in relation to the Deccan Phase 1, 2 and 3 (modified from Fantasia et al., this issue). 

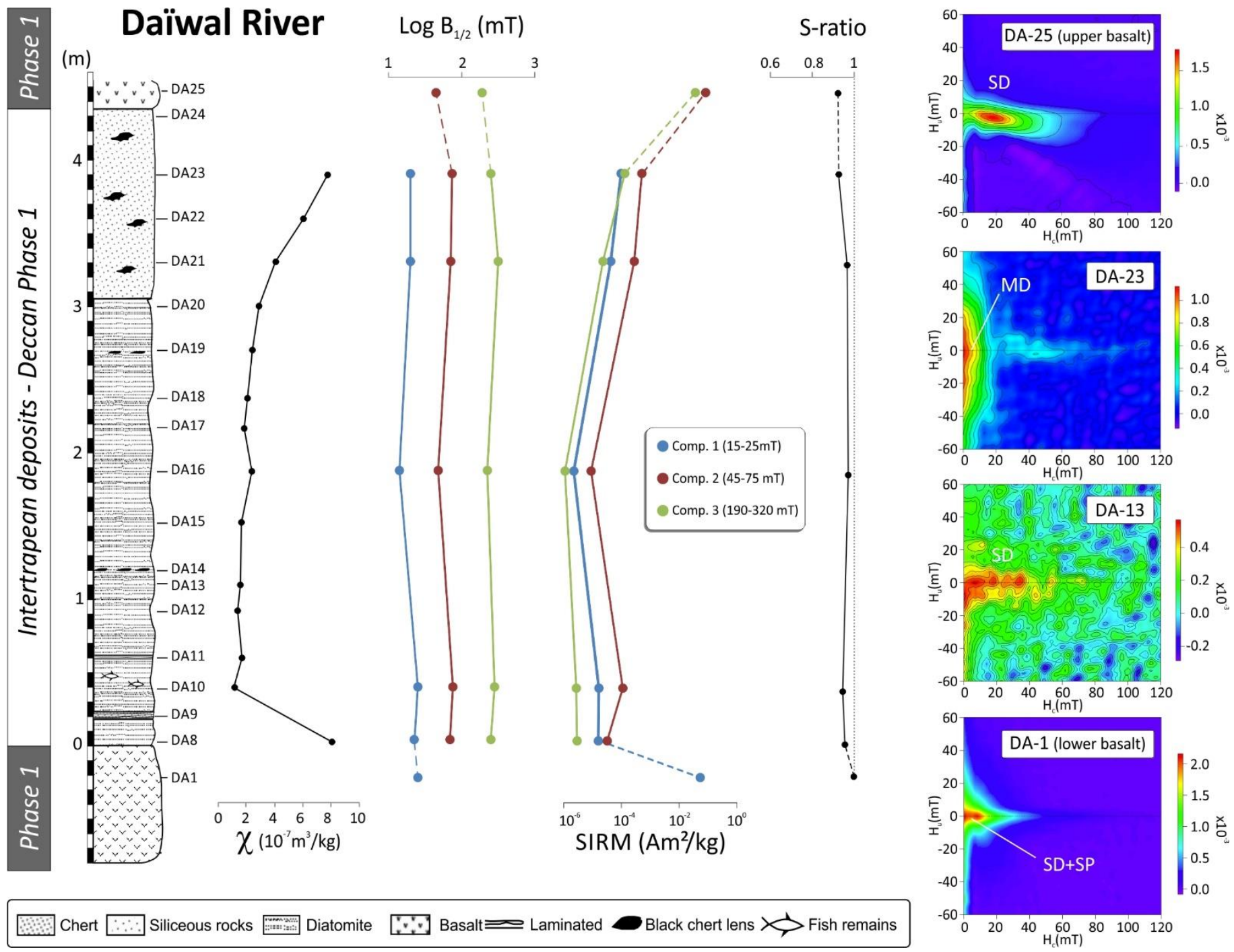

Figure 2. Magnetic ( $\chi$, IRM-CLG parameters and FORC diagram) data of the Daïwal River sediments interstratified within Deccan Phase-1 basalts. SIRM is the IRM at saturation, while $B_{1 / 2}$ corresponds to the component coercivity. Sratio corresponds to -IRM-0.3т/IRM $\mathrm{IT}_{1 \mathrm{~T}}$. The lower and upper basalt units share the same $\mathrm{B}_{1 / 2}$ and $\mathrm{S}$-ratio values as the lacustrine sediments suggesting that most of the iron oxides contained in the latter are inherited from the weathering of the underlying basalts. 


\section{A) Daïwal river}

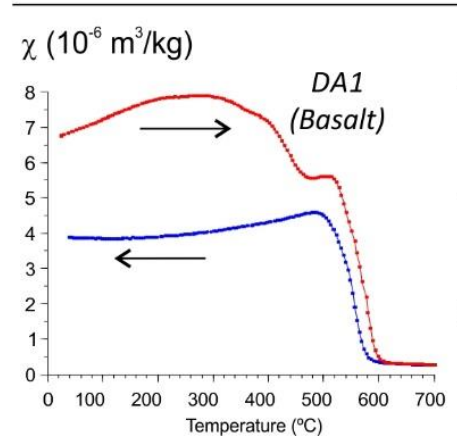

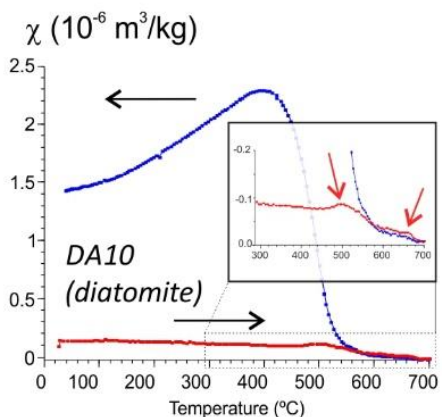

\section{B) Dhapewada}

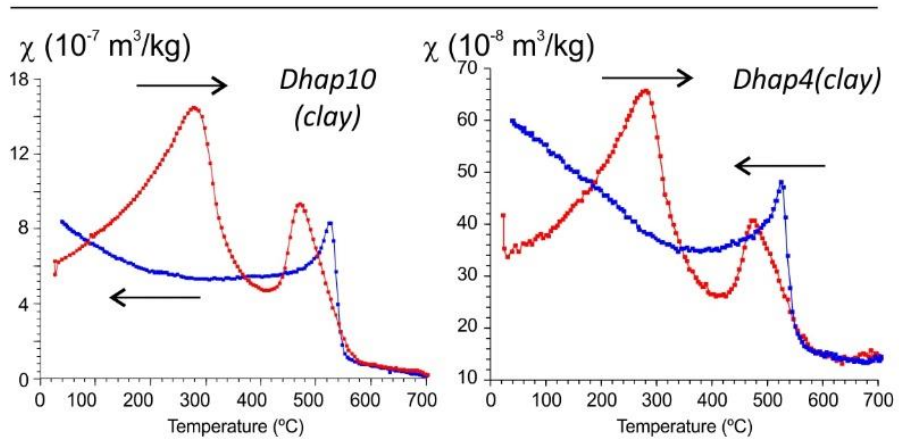

C) Dhapewada Dhap 10 (partial heating/cooling experiment)
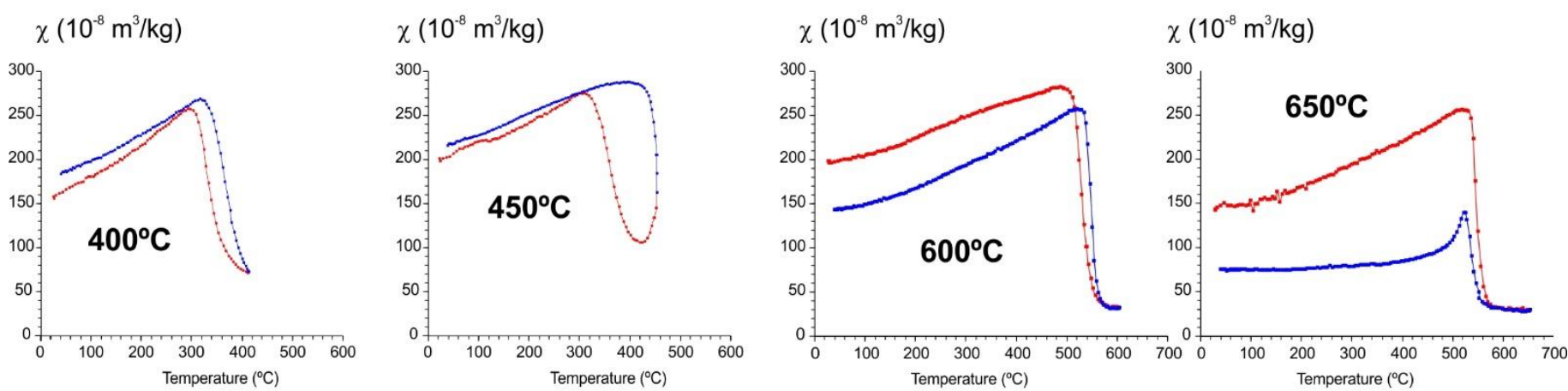

\section{D) Podgawan}
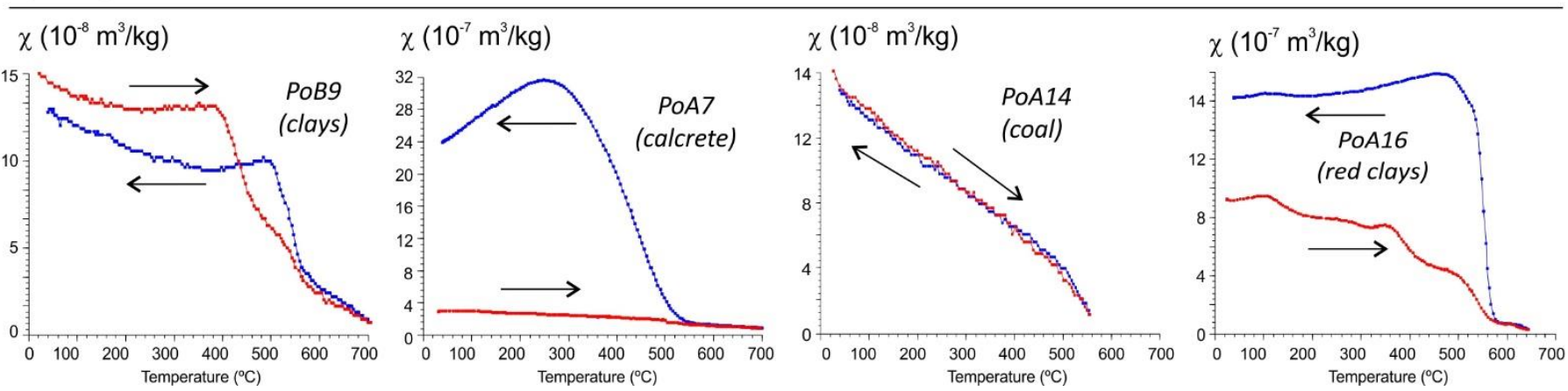

Figure 3. High-temperature dependence of low field mass specific magnetic susceptibility of the lacustrine sediments under study: A) Daiwal River, B) Dhapewada, C) Stepwise partial heating-cooling runs of sample Dhap10, and D) Podgawan. 


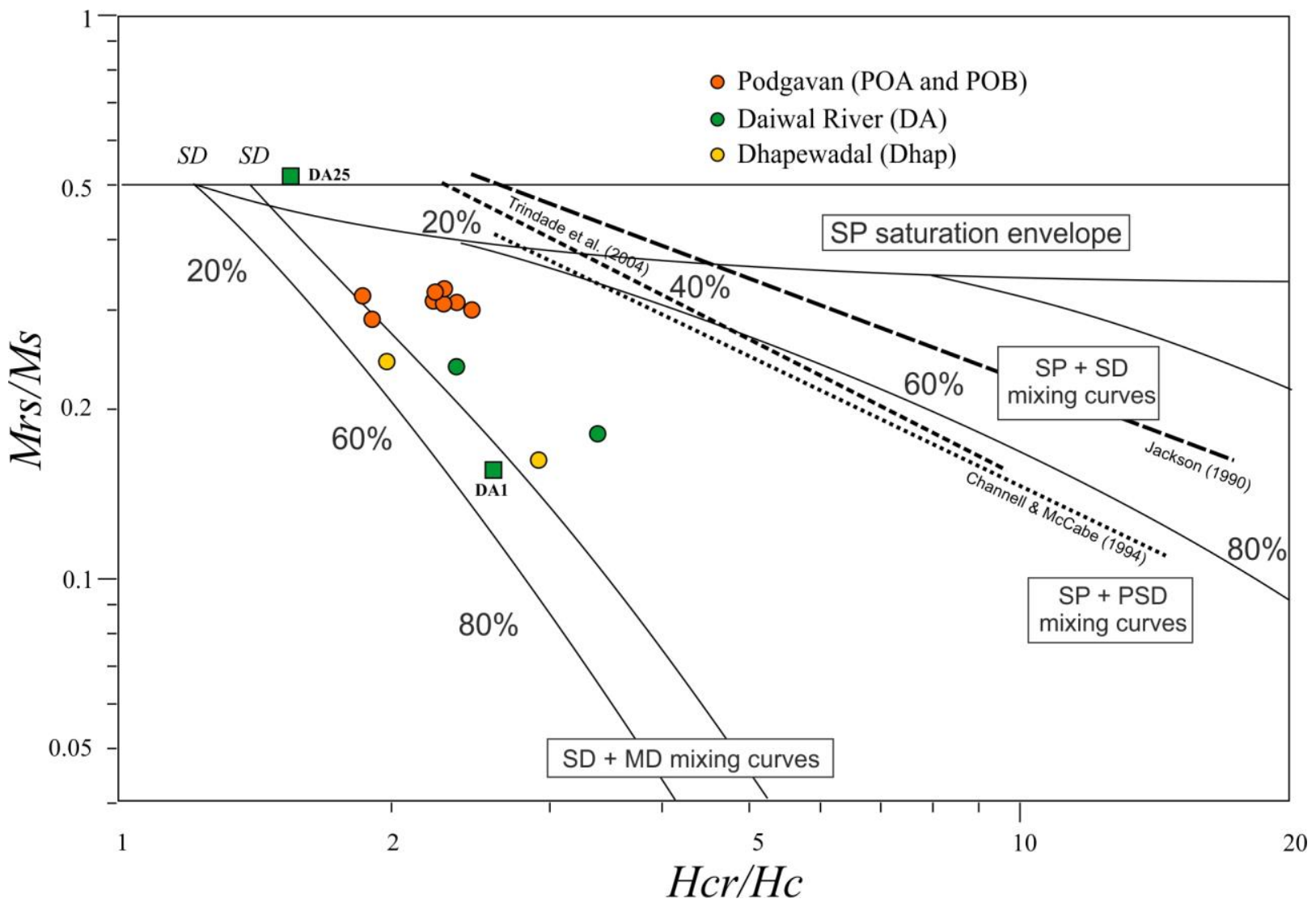

Figure 4. Day plot (Day et al., 1977) for 14 representative sediment samples from the Dhapewada, Daiwal River and Podgawan sections, including the lower and upper basalts of the Daiwal River (squares). The theoretical mixing curves for magnetite of Dunlop (2000a,b) are shown for comparison. Most of the samples follow the theoretical mixing curves $S D+M D$, showing a variable proportion of $M D$ particles from $<40 \%$ in the Podgawan sediments up to $40 \%$ in the Dhapewada and Daiwal River sediments. 


\section{¿}
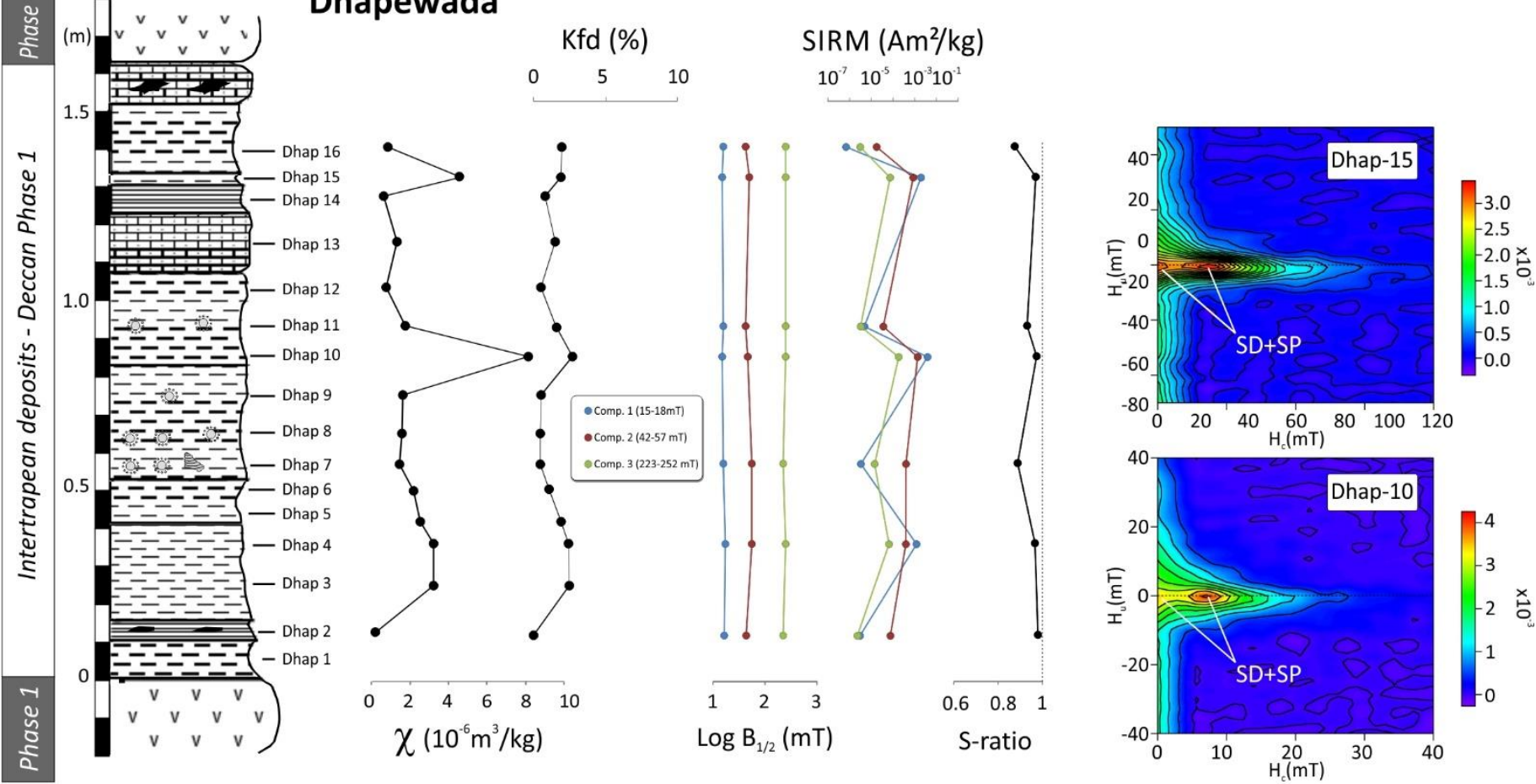

Clays $\quad \cdots$ Silty limestone Fossil clay $\quad$ Bask chert lens

Black chert

Gastropods

Figure 5. Magnetic ( $\chi, \mathrm{Kfd}$, IRM-CLG parameters, S-ratio and FORC diagram) data of the Dhapewada sediments interstratified within Deccan Phase-1 basalts. SIRM is the IRM at saturation, while $B_{1 / 2}$ corresponds to the component coercivity. S-ratio corresponds to -IRM-0.3 $/ \mathrm{IRM}_{1 \mathrm{~T}}$. 


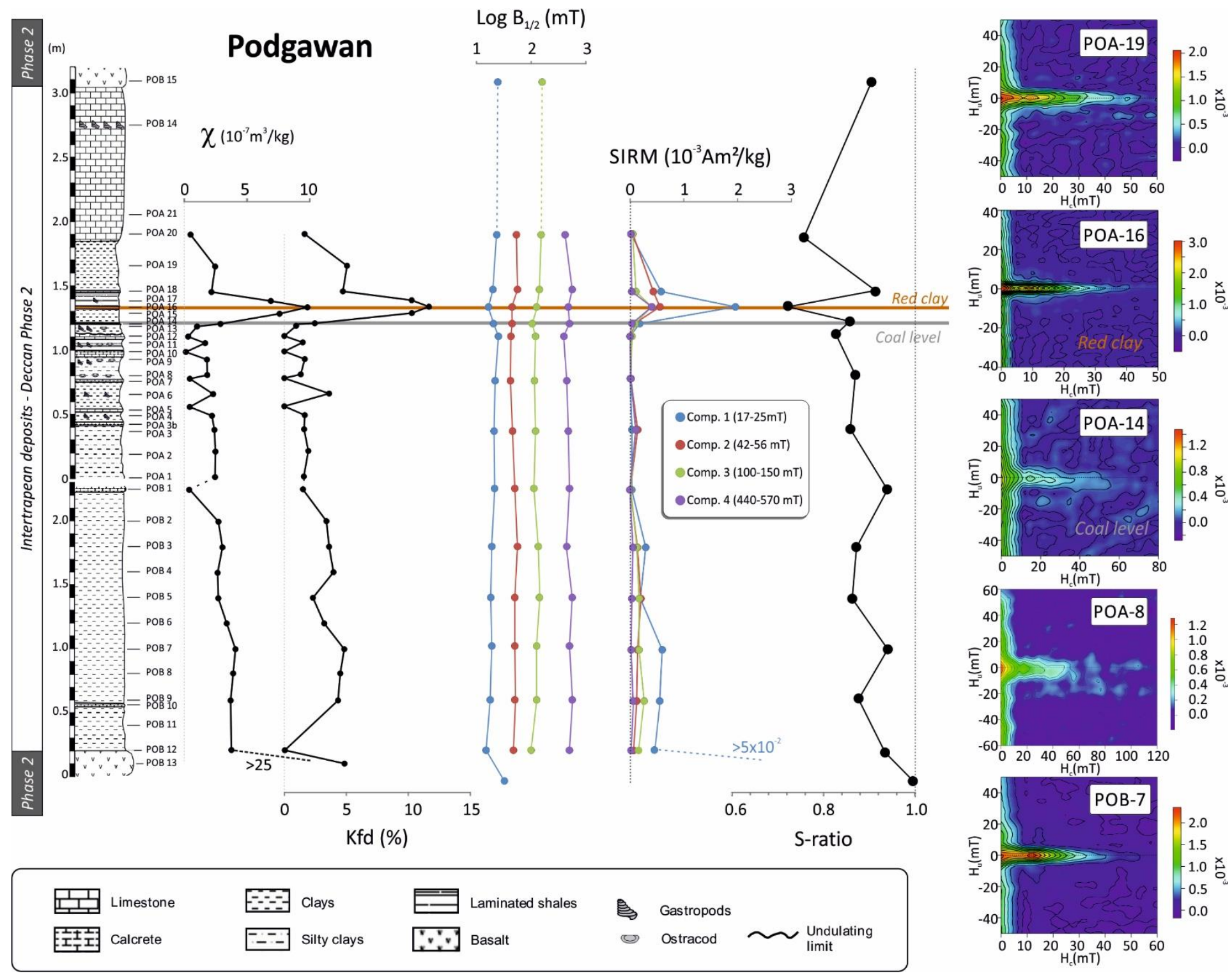

Figure 6. Magnetic ( $\chi, \mathrm{Kfd}$, IRM-CLG parameters, S-ratio and FORC diagram) data of the Podgawan sediments. SIRM is the IRM at saturation, while $B_{1 / 2}$ corresponds to the component coercivity. S-ratio corresponds to - IRM $_{-0.3 T} / I_{R M} M_{1 T}$. 


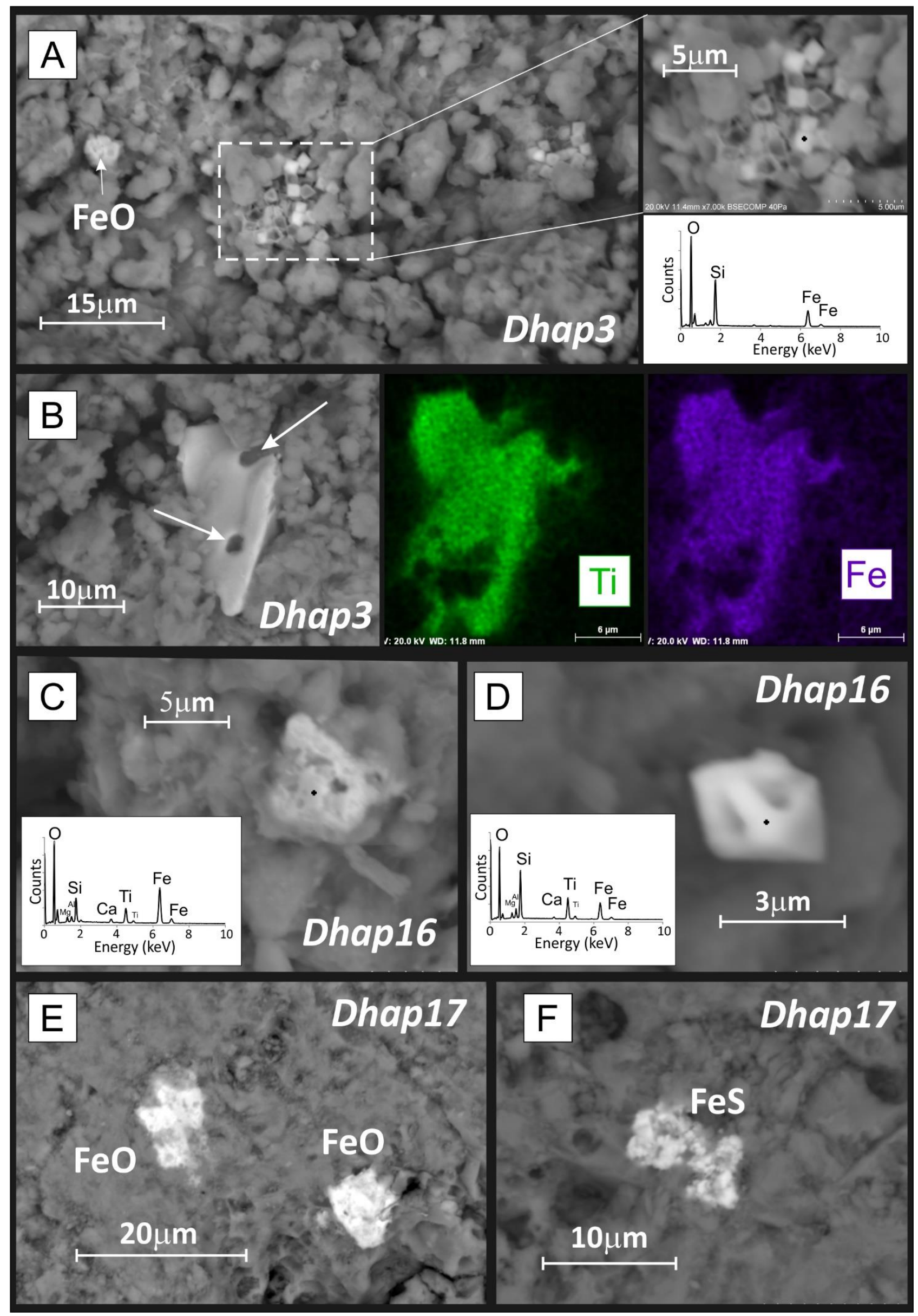

Figure 7. Scanning Electron Microscopy (SEM) observation coupled to Energy Dispersive Spectra (EDS) analysis of the Dhapewada (Dhap3, Dhap16 and Dhap17) samples. A) Framboids of iron oxide crystals (magnetite from pyrite conversion?). B) SEM photograph and EDS compositional mapping of a coarse ( $>20 \mu \mathrm{m})$ Ti-bearing iron oxide (titanomagnetite?) with dissolution features (white arrows). C) Fine $(\sim 10 \mu \mathrm{m})$ and eroded (detrital) titanomagnetites. D) Euhedral magnetite spinel. E) Iron oxides (or hydroxydes?) without Ti. F) Anhedral crystal of iron sulphide. 


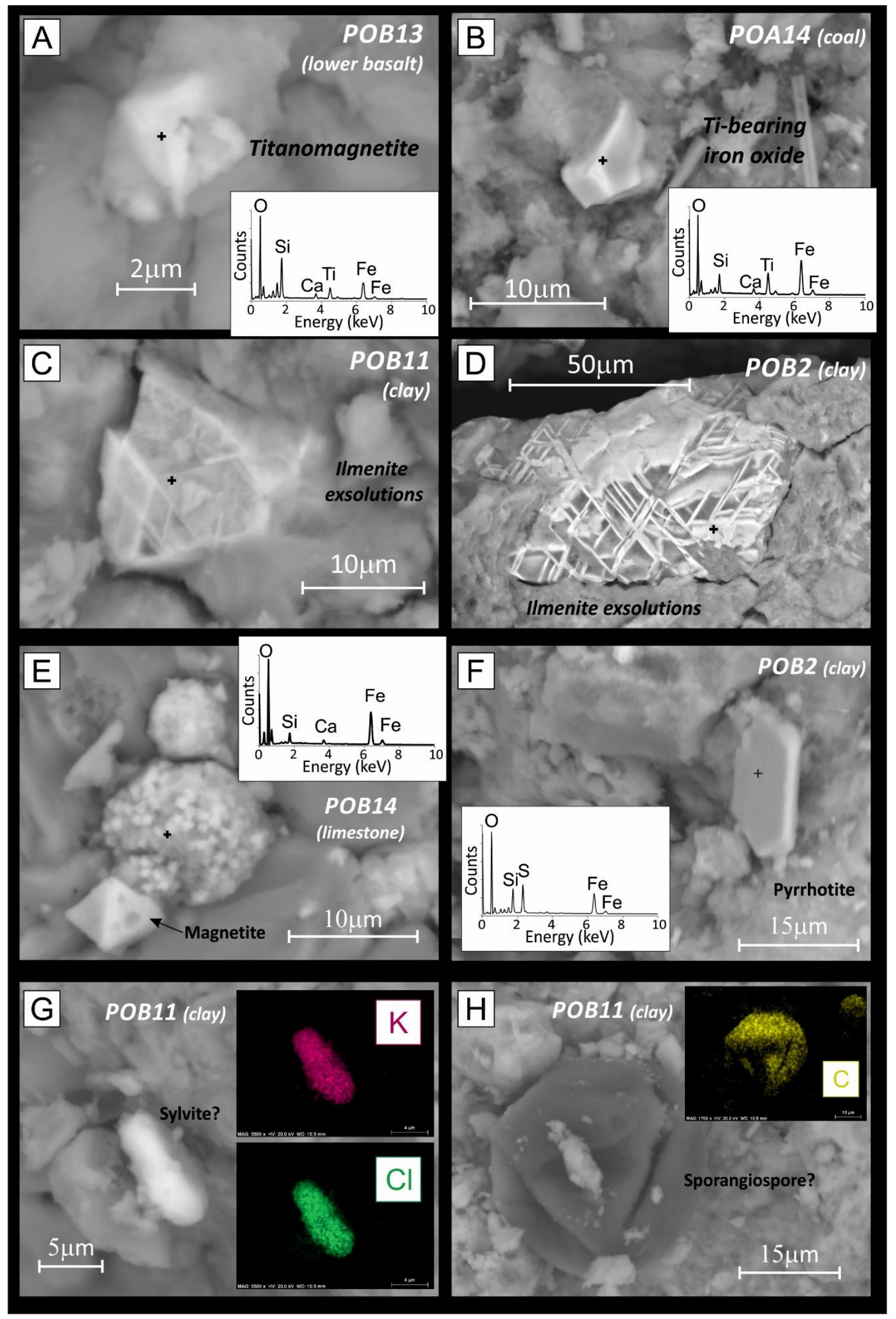

Figure 8. Scanning Electron Microscopy observation coupled to Energy Dispersive Spectra analysis of the iron oxides of the Podgawan samples. A) The lower basalt (POB13) contains small ( $10 \mu \mathrm{m})$ iron oxides with cubic-like structure and subhedral shapes resembling to magnetite. Ti is either absent or in moderate amounts; B) Similar Ti-bearing iron oxide observed in the coal-rich sediment (POA14); C) Presence of magnetite with exsolution textures indicate an igneous (detrital) origin for the iron oxides; D) Idem for larger ( $100 \mu \mathrm{m})$ ilmenite grains with exsolution features; E) Pyrite framboid transformed in magnetite; F) Semi-hexagonal and plate-like iron sulphur (pyrrhotite); G) Sylvite (KCl) is frequently observed in the Podgawan samples and present detrital aspects with grain size of $\sim 5 \mu \mathrm{m} ; \mathrm{H}$ ) An isolated organic compound (Myccorhiza fungi?) is locally observed in POB11. The flattened shape is due to vacuum. 


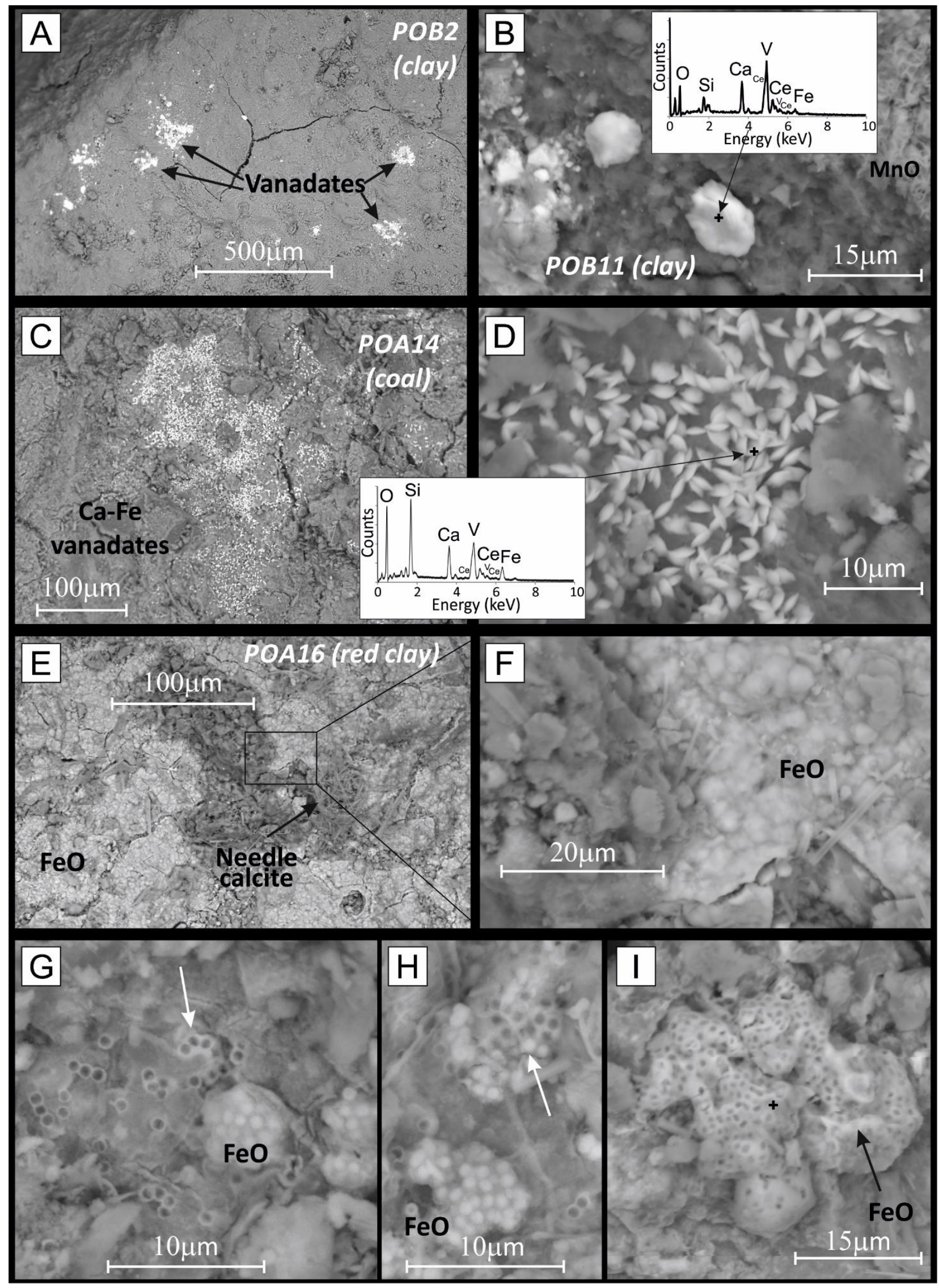

Figure 9. Scanning Electron Microscopy observation coupled to Energy Dispersive Spectra analysis of Podgawan samples (suite). A) Large ( $100 \mu \mathrm{m})$ aggregates of Fe-vanadates. B) The vanadates crystals also contain $\mathrm{Ca}$ and $\mathrm{Ce}$ as other constituent elements; C-D) In sample POA14 (coal), vanadate crystals have a disk-like morphology with grain size inferior to $1 \mu \mathrm{m}$; E) Crust of iron oxide/hydroxide are ubiquitously observed in the red clay sample (POA16). Needlefiber calcite are also ubiquitously encountered and present well crystallized shape of 10-20 $\mu \mathrm{m}$ long and less than $1 \mu \mathrm{m}$ in diameter; F) Under higher resolution, the thickness of the crust is less than $1 \mu \mathrm{m}$ and coat the surface of clay materials; G) Interestingly, enigmatic "bubble structure" systematically associated to iron oxide-rich crust show a very well-organized structures similar to bacterial chains; $\mathrm{H}$ ) Photograph showing that the tiny iron microspheres originated from the bubble structure; I) Enigmatic iron oxides showing dissolution features or suggesting a bacterial origin. 


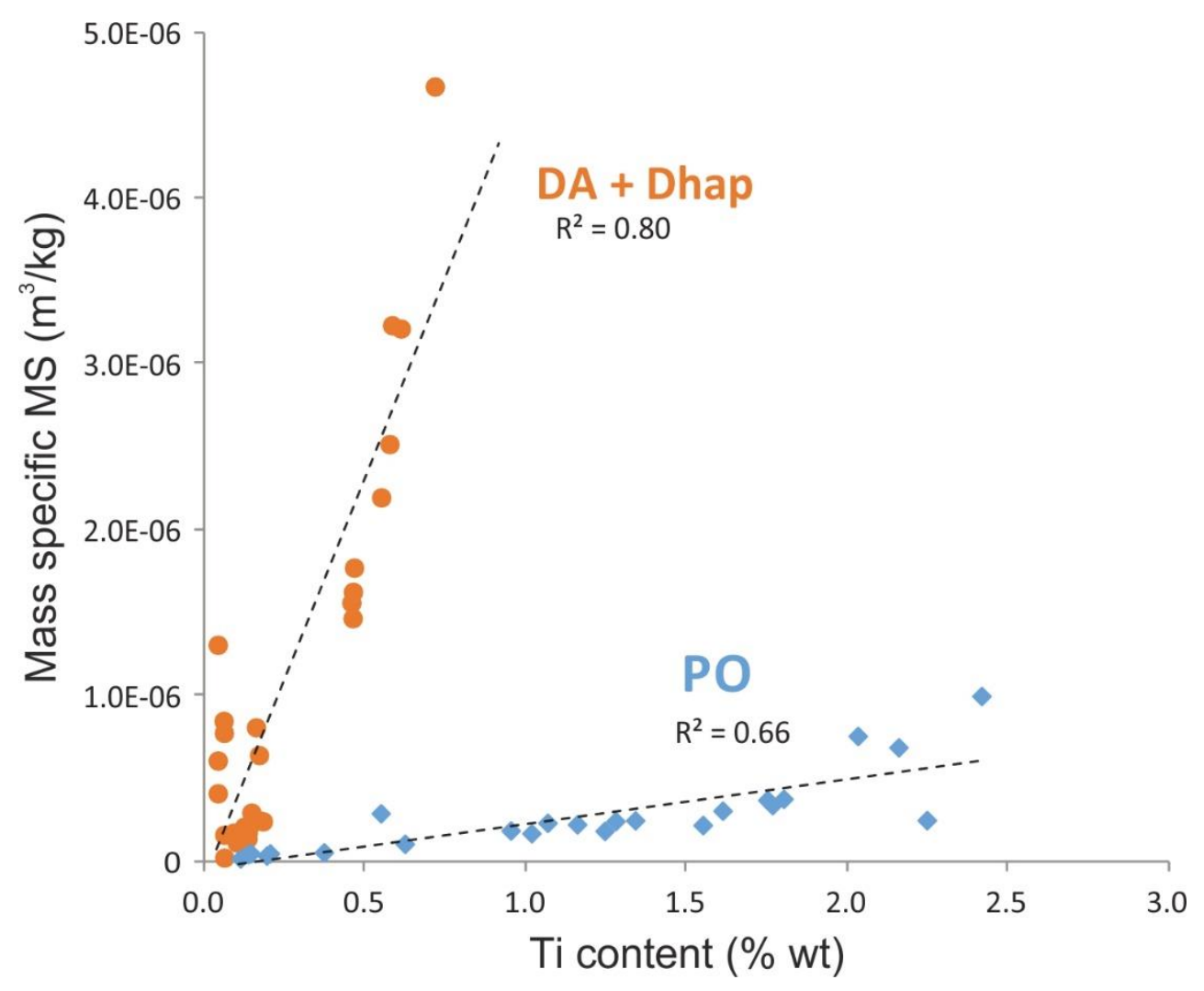

Fig. 10. Correlation between mass specific magnetic susceptibility and Ti content (in \%wt). The positive correlation observed in all studied lake suggest an allogenic (detrital) origin for the main magnetic carriers. 


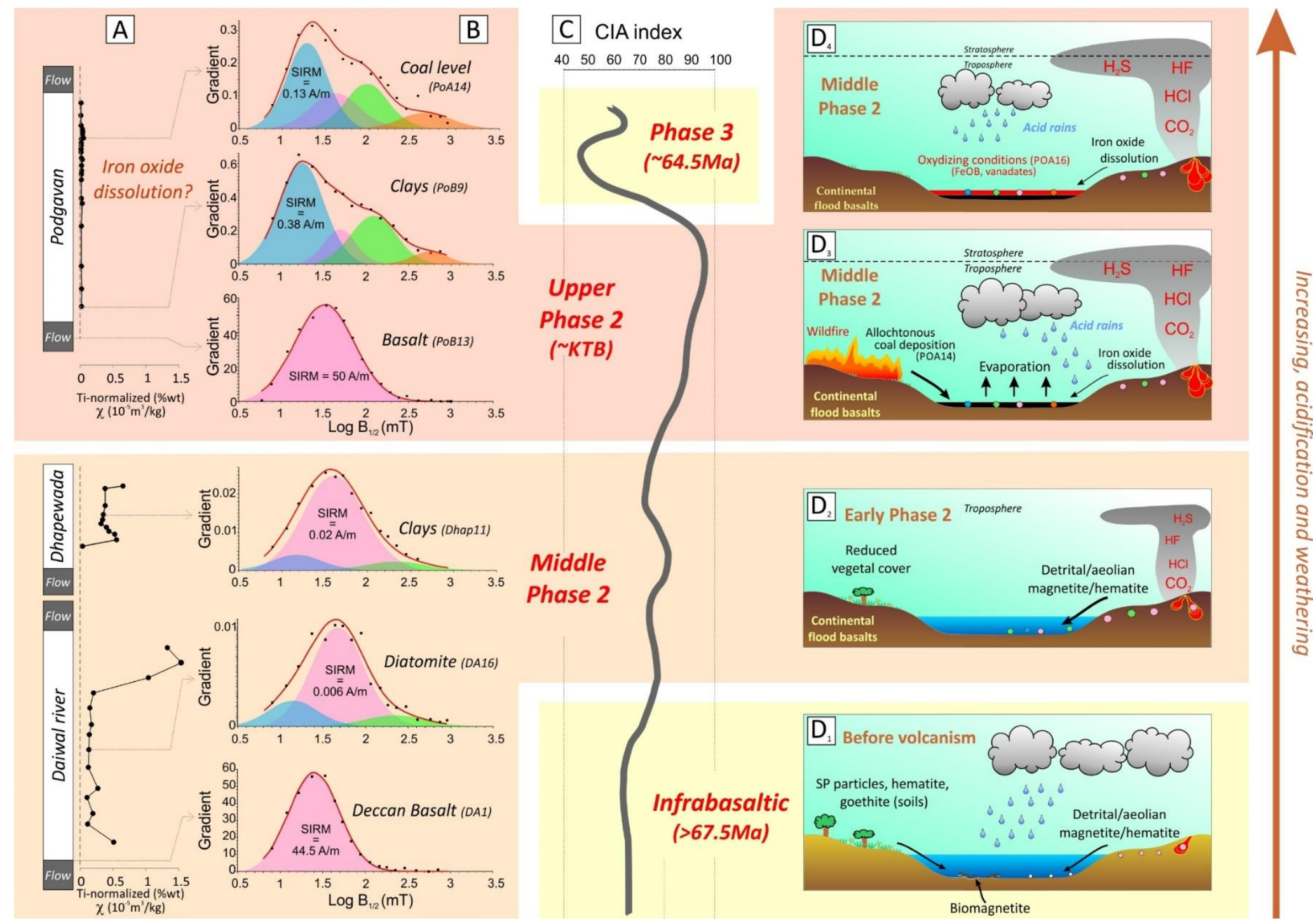

Fig. 11. Conceptual model of environmental lacustrine and continental settings during Deccan Phase 2 . (A) $\chi\left(10^{-6} \mathrm{~m}^{3} / \mathrm{kg}\right)$ normalized by Ti-content (\%wt) is drastically lower in the Podgawan section, suggesting dissolution effect linked to acid conditions. (B) Number of IRM components (illustrated here by the cumulative Gaussian curves) are systematically higher in the Podgawan samples suggesting additional input of iron oxides and/or active mineralogical transformations linked to higher weathering conditions. (C) Chemical Alteration Index (CIA) modified from Fantasia et al. (this volume). (D) Possible scenario showing, from the bottom to the top, ( $\left.D_{1}\right)$ hypothetical lacustrine settings of sub-tropical climate with the potential source of iron oxides (pedogenic, aeolian, detrital, biogenic). $\left(D_{2}\right)$ In contrast, the Daïwal River and the Dhapewada lakes under study are devoid of biogenic particles, probably due to acidification induced by Deccan volcanism. $\left(D_{3}\right)$ At the end of Phase 2 eruptions, the cumulative effect of greenhouse gases and acid aerosol releases led to drastic environmental changes including wildfires and subsequent deposition of the allochtonous coal layer (POA14). ( $\left.D_{4}\right)$ Increasing acid rains by huge input of $\mathrm{H} 2 \mathrm{~S}$ in the atmosphere, widespread vanadates crystallzation occurred, as well as the development of opportunist algae (iron oxidizing bacteria, FeOB) and iron oxide-hydroxide pigment nucleation. 


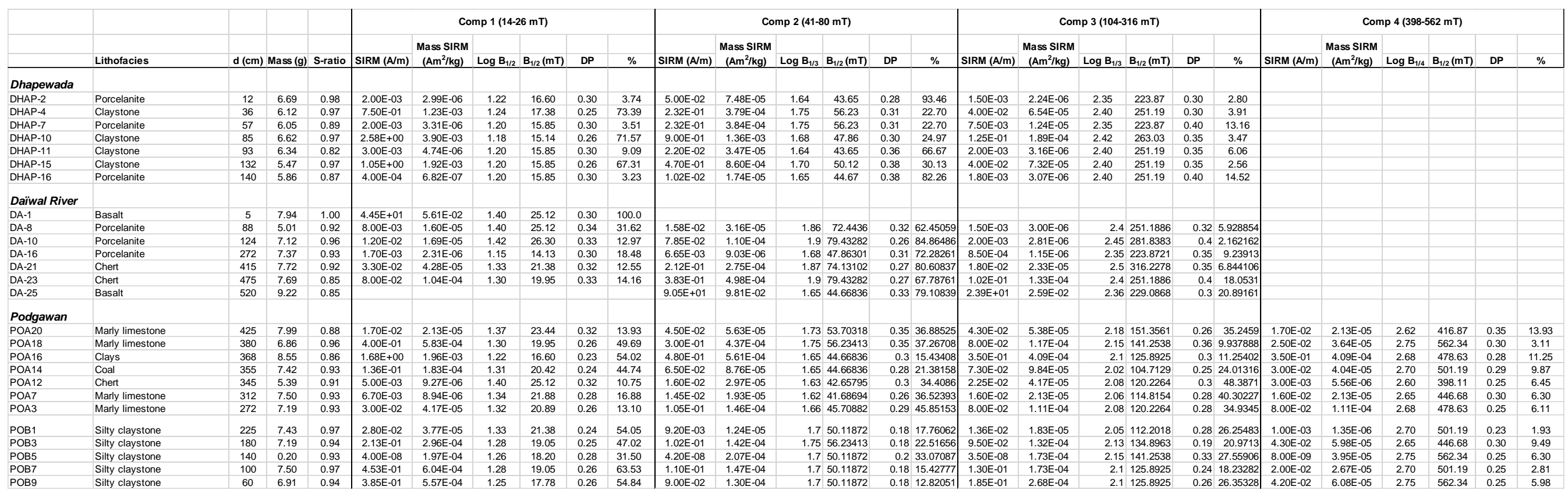

Table 1. Lithofacies, distance from the base of the section, mass of the samples and magnetic parameters obtained from the CLG log-Gaussian analysis. S ratio is calculated by using the formula $-\mathrm{IRM}_{-0.3 \mathrm{~T}} / \mathrm{IRM}_{1 \mathrm{~T}}$; Mass SIRM is the mass normalized saturation isothermal remanent magnetization; $\mathrm{B}_{1 / 2}=\mathrm{mean}$ coercivity in $\mathrm{mT} ; \mathrm{DP}=$ Dispersion parameter and $\%$ is the percentage of remanence contribution. 